NBER WORKING PAPER SERIES

\title{
RELATIVE PRICES AND
}

RELATIVE PROSPERITY

\author{
Chang-Tai Hsieh \\ Peter J. Klenow \\ Working Paper 9701 \\ http://www.nber.org/papers/w9701
}

\section{NATIONAL BUREAU OF ECONOMIC RESEARCH 1050 Massachusetts Avenue Cambridge, MA 02138}

May 2003

We are grateful to Francesco Caselli, Bill Easterly, J. Bradford DeLong, Gene Grossman, Chad Jones, Sam Kortum, Bob Lucas, Casey Mulligan, David Romer, Nancy Stokey, Alan Taylor, and Fabrizio Zilibotti for helpful comments. The views expressed herein are those of the authors and not necessarily those of the National Bureau of Economic Research.

(C2003 by Chang Tai Hsieh and Peter J. Klenow. All rights reserved. Short sections of text not to exceed two paragraphs, may be quoted without explicit permission provided that full credit including Cnotice, is given to the source. 
Relative Prices and Relative Prosperity

Chang-Tai Hsieh and Peter J. Klenow

NBER Working Paper No. 9701

May 2003

JEL No. O4, O1, E2

\section{$\underline{\text { ABSTRACT }}$}

The positive correlation between PPP investment rates and PPP income levels across countries is one of the most robust findings of the empirical growth literature. We show that this relationship is almost entirely driven by differences in the price of investment relative to output across countries. When measured at domestic prices rather than at international prices, investment rates are little correlated with PPP incomes. We find that the high relative price of investment in poor countries is solely due to the low price of consumption goods in poor countries. Investment prices are no higher in poor countries than in rich countries. These facts suggest that the low PPP investment rates in poor countries are not due to low savings rates or to high tax or tariff rates on investment. Poor countries instead appear to be plagued by low efficiency in producing investment goods and in producing exportables to trade for machinery and equipment.

Chang-Tai Hsieh Woodrow Wilson School 411 Robertson Hall

Princeton University

Princeton, NJ 08544

and NBER

chsieh@princeton.edu
Peter J. Klenow

Research Department

Federal Reserve Bank of Minneapolis

90 Hennepin Avenue

Minneapolis, MN 55480-0291

and NBER

Pete@klenow.com 


\section{Introduction}

One of the strongest relationships established in the empirical growth literature is the positive correlation between the investment rate in physical capital and the level of output per worker. As illustrated by figure 1, a well-known stylized fact is that the PPP investment rate of wealthy countries such as Norway and the U.S. is roughly 2 to 3 times higher than that of poor countries such as Mali and Kenya. This positive correlation also holds when considering the growth rate, rather than the level, of output per worker. ${ }^{1}$ Based on this evidence, empirical work accounting for why some countries are rich and others are poor has assigned an important role to differences in physical capital intensity. ${ }^{2}$

Two broad sets of explanations have been proposed for the low PPP investment rates in poor countries. The first set of explanations operates through savings rates (combined with limited international capital mobility). Prime examples are theories in which poor countries have low savings because of institutions and policies that result in high effective tax rates on capital income (e.g., financial repression). ${ }^{3}$ Other authors have argued that poor countries are stuck in low-savings traps because of subsistence consumption needs. ${ }^{4}$ Regardless of the underlying mechanism, the notion that poor countries have low savings was central to the way development

\footnotetext{
${ }^{1}$ Levine and Renelt (1992) single out the investment rate as the lone robust correlate with growth in income per person. Sala-i-Martin (1997) finds the investment rate to be significantly correlated with growth in $99.97 \%$ of the 32,509 cross-country regressions he ran with investment alongside other regressors.

${ }^{2}$ See Mankiw, Romer and Weil (1992), Klenow and Rodríguez-Clare (1997), and Hall and Jones (1999).

${ }^{3}$ See McKinnon (1973). Poor countries have also been hypothesized to have low savings rates because of high dependency ratios (Higgins and Williamson, 1997), high discount rates (Carroll et al., 1994), and high explicit tax rates on capital income (Easterly and Rebelo, 1993).

${ }^{4}$ The earliest papers were by Nelson (1956) and Solow (1956). More recent papers include Gersovitz (1983), Matsuyama (1992), and Ben-David (1998).
} 
economists in the 1950s and 1960s thought about the world, and was an important intellectual foundation for the lending work of institutions like the World Bank. ${ }^{5}$

A second set of explanations focuses on forces that directly affect investment. A number of recent papers argue that poor countries have policies and institutions that drive up the cost of capital. According to this view, poor countries have low PPP investment rates because they tax capital goods, have barriers to capital goods imports, or grant monopoly rights to domestic capital goods producers. Advocates of this view typically point to the stylized fact that the relative price of capital is 2 to 3 times higher in a poor country than in a rich country. ${ }^{6}$

Investment distortions have also played a prominent role in historical accounts of countries that have experienced dramatic reversals of fortune. For example, Diaz-Alejandro (1970) tells how policies introduced by Peron in Argentina to redistribute income to the urban working class had the effect of doubling the price of capital. Diaz-Alejandro argues this distortion was responsible for Argentina's slide from being one of the wealthiest countries in the world 60 years ago to where it is today. ${ }^{7}$

In this paper, we present a series of facts to shed light on the underlying causes of differences in PPP investment rates across rich and poor countries. The first fact involves the rate of investment at international prices versus at domestic prices. ("International prices" — or "PPP prices" - are a quantity-weighted average of domestic prices across countries, and hence

\footnotetext{
${ }^{5}$ Lewis (1954, p. 155): “The central problem in the theory of development is to understand the process by which a community which was previously saving and investing 4 or $5 \%$ of its national income or less, converts itself into an economy where voluntary saving is running at about 12 to $15 \%$ of national income or more." Rostow (1960) saw savings as the necessary trigger for takeoff into development. Bhagwati (1966) advocated taxes to boost national saving, and Chenery and Strout (1966) advocated foreign aid. Easterly (2001, chapter 2) discusses the influence of this "financing gap" view of underdevelopment in the lending work of international financial institutions.

${ }^{6}$ See Jones (1994), Lee (1995), Chari, Kehoe, and McGrattan (1996), McGrattan and Schmitz (1999), Collins and Williamson (2001), Eaton and Kortum (2001), and Restuccia and Urrutia (2001).

${ }^{7}$ See Taylor (1998a, 1998b) for more recent accounts of the Argentinian case.
} 
do not vary across countries.) When evaluated at domestic prices, richer countries have only modestly higher investment rates than poorer countries do. Figure 2 illustrates this for 114 countries in 1996. Whereas the correlation between the PPP investment rate and PPP income is 0.50 , that between the domestic-price investment rate and PPP income is only $0.05 .^{8}$ At domestic prices, poor countries like Mali and Kenya do not invest much less than rich countries such as the U.S. or Norway. This evidence undermines explanations involving discount rates, subsistence consumption, low-savings traps, and the taxation of capital income. Instead, the domestic relative price of investment — which accounts for the difference between investment rates at domestic prices vs. at international prices - is much higher in poor countries.

The second stylized fact is that the high relative price of investment in poor countries is entirely driven by the denominator rather than the numerator. We find that investment goods are no more expensive in poor countries than in rich countries, whereas consumption prices tend to be lower in poor countries. This contradicts the hypothesis that investment goods are taxed more heavily in poorer countries, or are subject to high tariffs or transportation costs that make them expensive for poor countries. Put differently, if investment distortions are responsible for the high relative price of capital goods in Mali, then a computer in Mali should cost 2 to 3 times more than a computer in the U.S. Instead, computers in Mali cost roughly the same as in the U.S., and what is responsible for the high relative price of capital in Mali is that nontradable services are much cheaper in Mali than in the U.S.

\footnotetext{
${ }^{8}$ The drop is from 0.58 to 0.03 when we exclude the four countries with very high PPP investment rates (Turkmenistan, Thailand, Korea and Singapore). When we exclude the two countries with very high investment rates at domestic prices (Congo and Turkmenistan), the drop is from 0.56 to 0.16 . When we weight countries by their Penn World Table data quality grade, with $\mathrm{A}=4$ (19 countries, all in the OECD), $\mathrm{B}=3$ (14 countries), $\mathrm{C}=2$ (76 countries), and $\mathrm{D}=1$ (the five countries Belarus, Tajikistan, Turkmenistan, Uzbekistan, and Yemen), the drop is from 0.54 to 0.02 .
} 
These facts point to important differences in the productivity of the investment goods sector (and other tradable sectors) across countries. Poor countries appear to have low investment rates in PPP terms primarily because their investment sectors have low productivity compared to their consumption sectors. This interpretation is entirely consistent with investment goods being internationally tradable (even perfectly so), but does require that not all consumption be costlessly tradable. To the extent that investment goods are more easily traded than consumption goods and services, this is a corollary to the Balassa-Samuelson hypothesis that poor countries have low productivity in tradables relative to nontradables. ${ }^{9}$

Our results imply that the covariation of physical capital investment rates and income arises from a deeper productivity puzzle. The challenge is not just to explain low overall productivity in poor countries, but to explain low productivity in investment goods production relative to consumption goods production (and, more generally, low productivity in tradables relative to nontradables).

The rest of this paper proceeds as follows. In section 2 we present a model in which a country's investment rate and income level are endogenous to its tax rate on capital income, its tax rate on producing and importing investment goods, and its productivity in producing investment and consumption goods, respectively. In section 3 we compare the predictions of the model to Penn World Table benchmark data on investment rates at domestic and international prices, investment prices, consumption prices, and PPP income levels. In section 4 we summarize.

\footnotetext{
${ }^{9}$ See Balassa (1964) and Samuelson (1964), and also Bhagwati (1984). Summers and Heston (1991) document this phenomenon, using services as a proxy for nontradables.
} 


\section{A Model with Endogenous Investment Rates and Income Levels}

We consider a simple model with two sectors and two tax rates: a nontradable consumption sector, a tradable investment sector, a tax rate on importing and producing investment goods, and a tax rate on capital income. We use the capital income tax rate as a stand-in for many potential determinants of a country's saving rate. Aside from having separate consumption and investment sectors, it is a conventional neoclassical growth model. After laying out the model, we will show how the two tax rates and productivity levels affect a country's price of investment, price of consumption, PPP investment rate, and PPP income per worker. Our aim is to identify telltale markings these forces should leave in the data.

In the model, each of $L_{j}$ workers in country $j$ inelastically supplies one unit of labor each period. The representative worker chooses current consumption to maximize

$$
\sum_{t=0}^{\infty} \beta^{t} \frac{C_{j, t}^{1-1 / \sigma}}{1-1 / \sigma}
$$

subject to the constraints

$$
\begin{aligned}
& K_{j, t+1}=(1-\delta) K_{j, t}+I_{j, t}, \\
& P_{C_{j, t}} C_{j, t}+P_{I_{j, t}} I_{j, t}=w_{j, t}+\left[R_{j, t}-\tau_{K_{j}}\left(R_{j, t}-\delta P_{I_{j, t}}\right)\right] K_{j, t}+T_{j, t} \text {, and } \\
& R_{j, t}=\frac{r_{j, t}+\delta-\delta \tau_{K_{j}}}{1-\tau_{K_{j}}} P_{I_{j, t}}
\end{aligned}
$$

Here $C$ is real consumption, $\beta$ is the discount factor, $\sigma$ is the intertemporal elasticity of substitution, $K$ is the real stock of physical capital, $I$ is real investment, $\delta$ is the depreciation rate on physical capital, $w$ is the wage, $R$ is the rental price of capital, $\tau_{K}$ is the tax rate on 
(after-depreciation) capital income, $P_{I}$ is the domestic price of investment goods, $T$ are transfers from the government, $P_{C}$ is the domestic price of consumption goods, and $r$ is the real interest rate net of depreciation and taxes. The CRRA utility function and geometric depreciation are standard assumptions. The transfers are rebated tax collections (the model has no government purchases or production), which each worker takes as given. The flow budget constraint says disposable income not spent on consumption is devoted to investment goods.

We assume that consumption goods cannot be traded internationally, whereas investment goods are fully tradable. Empirically, some consumption is in fact tradable (e.g., clothing and cars) and not all investment is tradable (e.g., some construction services). ${ }^{10}$ In the empirical section that follows we contrast the most nontradable forms of consumption with the most tradable components of investment. Specifically, we compare services consumption with investment in machinery and equipment. For expositional simplicity we model the polar case of purely nontradable consumption and fully tradable investment.

We assume that there is a pre-tax world price of investment that each country takes as beyond its control. The price of investment goods in country $j$ is pinned down by the world price plus the country-specific tax and tariff rate $\tau_{I}$ that applies to producing and importing (but not exporting) investment goods. Suppressing time subscripts here and below, we have:

$$
P_{I_{j}}=\left(1+\tau_{I_{j}}\right) P_{I}^{\text {world }}
$$

\footnotetext{
${ }^{10}$ In the first section of the appendix, we modify the model to allow for tradable consumption goods that can be exchanged for investment goods.
} 
In each country $j$, firms rent capital and hire labor in competitive spot markets. Firms sell their output in competitive markets in order to maximize static profits. For firms producing consumption and investment goods, respectively, current profits are

$$
\begin{gathered}
P_{C_{j}} C_{j}-w_{j} L_{C_{j}}-R_{j} K_{C_{j}} \text { and } \\
P_{I_{j}}{ }_{j}{ }_{j}-\tau_{I_{j}} P_{I}^{\text {world }} I_{j}-w_{j} L_{I_{j}}-R_{j} K_{I_{j}} .
\end{gathered}
$$

The production technologies in the two sectors are

$$
\begin{gathered}
C_{j}=A_{C_{j}} K_{C_{j}}^{\alpha} L_{C_{j}}^{1-\alpha} \text { and } \\
I_{j}=A_{I_{j}} K_{I_{j}}^{\alpha} L_{I_{j}}^{1-\alpha} .
\end{gathered}
$$

$A_{C}$ and $A_{I}$ are exogenous productivity indices. $\alpha \in(0,1)$ is the elasticity of output with respect to physical capital, and $(1-\alpha)$ that with respect to labor. We assume these elasticities are the same across countries and across sectors. Gollin (2002) finds that payments to physical capital range from $20 \%$ to $35 \%$ of GDP across countries, but that the variation is not correlated with country income. In the U.S., readily available data indicates that factor shares are very similar across the investment and consumption sectors. ${ }^{11}$

Using first order conditions from (3) through (6), one can show that

\footnotetext{
${ }^{11}$ Nonetheless, in the second section of the appendix we show that our central results carry through when we allow factor shares to differ between the two sectors. Our estimates of sectoral factor shares in the U.S. define Labor's Share $=$ Compensation $/$ (Value Added - Indirect Business Taxes - Proprietor's Income). Using U.S. Bureau of Economic Analysis data available at www.bea.gov, we calculated the average labor share over $1987-2000$ to be $78 \%$ in the consumption sector and $79 \%$ in the investment sector. In this calculation we excluded housing from consumption because only capital inputs are incorporated in the service flow from housing. The capital-intensity of housing pulls down the overall labor share in U.S. GDP to $67 \%$.
} 


$$
\begin{gathered}
R_{j}=\alpha P_{I}^{\text {world }} A_{I_{j}}\left(K_{j} / L_{j}\right)^{\alpha-1} \text { and } \\
\frac{P_{C_{j}}}{P_{I_{j}}}=\frac{A_{I_{j}}}{A_{C_{j}}\left(1+\tau_{I_{j}}\right)} .
\end{gathered}
$$

Equation (7) equates the rental price of capital to the marginal product of capital. Marginal products in the two sectors are equated to the common rental price. This implies a common capital-labor ratio in the two sectors equal to the economywide $K / L$. Expression (8) says the domestic price of consumption relative to investment is inversely related to relative TFP (Total Factor Productivity) in the two sectors, and decreasing in the tax rate on producing and importing investment goods. The relative price does not depend on the wage or real interest rate because both sectors face the same factor prices and use factors with the same intensity. The relative price also does not depend on the world price of investment, because the world price of investment anchors both domestic price levels.

The discount rate $(\beta)$, intertemporal elasticity $(\sigma)$, and depreciation rate $(\delta)$ are the same in all countries. Sectoral TFPs grow at the constant rate $g_{A}$ across sectors and across countries. ${ }^{12}$ What we allow to vary across countries are the tax rate on capital income $\left(\tau_{K_{j}}\right)$, the tax rate on producing and importing investment goods $\left(\tau_{I_{j}}\right)$, TFP in the investment sector $\left(A_{I_{j}}\right)$, and TFP in the consumption sector $\left(A_{C_{j}}\right)$. TFPs ascend parallel paths, but can differ across countries and across sectors at a point in time.

\footnotetext{
${ }^{12}$ In the third section of the appendix, we show that the results are virtually identical if we allow sectoral TFPs to grow at different rates. See Gordon (1990), Greenwood et al. (1997) and Mulligan (2002) for U.S. evidence that the relative price of investment trends downward, suggesting faster TFP growth in the investment sector.
} 
Variation in $\left(\tau_{K_{j}}, \tau_{I_{j}}, A_{I_{j}}\right.$, and $\left.A_{C_{j}}\right)$ generates cross-country variation in steady state levels of the investment rate at domestic prices, the domestic price of investment, and the domestic price of consumption. Differing country parameter values also yield differing levels of PPP income per worker at a point in time along steady state paths. No opportunities for international goods arbitrage exist by (2), plus the assumption that consumption is nontradable. Because capital income is taxed based on where the capital is located, there is also no incentive for international capital flows. After-tax, after-depreciation real interest rates are the same in all countries, and equal

$$
r_{j}=(1+g)^{1 / \sigma} / \beta-1
$$

Here $(1+g)=\left(1+g_{A}\right)^{1 /(1-\alpha)}$. Expression (9) follows from the consumption Euler equation and the steady state assumption. As no capital flows internationally, saving and investment rates (at domestic prices) are equal within countries, and countries own their domestic capital stocks.

Before expressing steady state values, it is useful to formally define the following:

$$
\begin{gathered}
\text { Domestic Price GDP }=Y_{j}=P_{C_{j}} C_{j}+P_{I_{j}} I_{j} \\
\text { PPP GDP }=Y_{j}^{\mathrm{PPP}}=P_{C}^{\mathrm{PPP}} C_{j}+P_{I}^{\mathrm{PPP}} I_{j} \\
\text { Domestic Price Investment Rate }=i_{j}=\frac{P_{I_{j}} Y_{j}}{Y_{j}} \\
\text { PPP Investment Rate }=i_{j}^{\mathrm{PPP}}=\frac{P_{I}^{\mathrm{PPP}} I_{j}}{Y_{j}^{\mathrm{PPP}} .}
\end{gathered}
$$


To determine each country's steady state path, we proceed as follows. We substitute (2) and (9) into (1) to pin down a country's rental price of capital. We substitute the rental price into (7) to solve for a country's capital-labor ratio, which is growing along with $A_{I_{j}}$ on the country's steady state path. We use the capital accumulation equation to infer the steady state investmentlabor ratio from the capital-labor ratio. We substitute both ratios into (6) and divide by $L_{j}$ to obtain the share of labor (and capital) devoted to investment goods production:

$$
L_{I_{j}} / L_{j}=\frac{(g+\delta) \alpha\left(1-\tau_{K_{j}}\right)}{\left(1+\tau_{I_{j}}\right)\left[(1+g)^{1 / \sigma} / \beta-1+\delta\left(1-\tau_{K_{j}}\right)\right]} .
$$

It is then straightforward to show that the steady state investment rate at domestic prices is

$$
i_{j}=\frac{\left(1+\tau_{I_{j}}\right) L_{I_{j}} / L_{j}}{1+\tau_{I_{j}} L_{I_{j}} / L_{j}} .
$$

Note that a country's investment rate at domestic prices does not depend on its sectoral TFPs. TFP levels do not affect the investment rate at domestic prices because the quantities and prices of investment and consumption respond in precisely offsetting ways. Our functional forms are, of course, important for this result. But these functional forms are standard in the growth and business cycle literatures, and for good reasons. The constant intertemporal elasticity of substitution is needed for the existence of steady state investment rates and real interest rates. And Cobb-Douglas production technologies are consistent with the stability of factor shares over time and across countries.

Given that all the parameter values lie between 0 and 1,(10) and (11) imply that the investment rate at domestic prices is strictly decreasing in both tax rates. To see why intuitively, we combine (1), (2), (7), and (9) to arrive at 


$$
\frac{r+\delta-\delta \tau_{K_{j}}}{1-\tau_{K_{j}}}\left(1+\tau_{I_{j}}\right)=\alpha A_{I_{j}}\left(K_{j} / L_{j}\right)^{\alpha-1}
$$

A higher capital income tax rate raises the left hand side and the (steady state) rental price of capital, so the right hand side and the (steady state) marginal product of capital must be higher. For a given level of TFP in the investment sector, a higher marginal product of capital requires a lower capital-labor ratio and therefore a lower PPP investment rate. The tax rate on capital income does not affect relative prices by (8), so the investment rate is lower at domestic prices as well as at international prices.

The negative effect of the investment tax on the investment rate follows similar logic. A higher tax rate on investment raises the rental price of capital, necessitating a higher marginal product of capital and a lower PPP investment rate. The negative effect on the investment rate at domestic prices is less transparent. A higher investment tax raises the relative price of investment goods in (8), a force for a higher investment rate at domestic prices. But the adverse effect on the quantity of investment is larger, leaving the domestic-price investment rate lower. From (10), (11) and $\alpha<1$, the capital-labor ratio must fall proportionately more than the taxinduced increase in the price of investment. As the real capital-labor ratio is proportional to a country's real investment rate (controlling for TFPs), the real investment rate must fall more than the price of investment rises, yielding a lower investment rate at domestic prices. ${ }^{13}$

The investment rate at international prices is

\footnotetext{
${ }^{13}$ For plausible parameter values we find this negative effect to be small. We illustrate this in figure 3 below.
} 


$$
{ }_{i}^{\mathrm{PPP}}=\frac{P_{I}^{\mathrm{PPP}} A_{I_{j}}{ }^{L_{I_{j}}}{ }^{/ L_{j}}}{P_{I}^{\mathrm{PPP}} A_{I_{j}}{ }_{L_{I_{j}}} / L_{j}+P_{C}^{P P P} A_{C_{j}}\left(1-L_{I_{j}} / L_{j}\right)} .
$$

From (10) and (13), the PPP investment rate is invariant to equiproportionate changes in sectoral TFPs. Low TFP in the investment sector relative to TFP in the consumption sector, however, does depress a country's PPP investment rate. It makes investment expensive just like high taxes on capital income or investment do. Because PPP prices of investment and consumption do not vary across countries, there is no offsetting relative price effect as operates on the investment rate at domestic prices. For the same reason, a higher investment tax rate lowers the PPP investment rate more than it lowers the domestic-price investment rate. In contrast, a higher capital income tax rate does not affect the relative price of investment and therefore has the same (negative) effect on investment rates at domestic and international prices.

Along steady state paths, PPP output per worker in country $j$ is

$$
Y_{j}^{\mathrm{PPP}} / L_{j}=\left[\frac{i_{j}^{\mathrm{PPP}}}{\mathrm{g}+\delta}\right]^{\frac{\alpha}{1-\alpha}}\left[\frac{A_{I_{j}}{ }^{{ } C_{j}}}{A_{I_{j}}\left(1-i_{j}{ }^{\mathrm{PPP}}\right)+A_{C_{j}} i_{j}^{\mathrm{PPP}}}\right]^{\frac{1}{1-\alpha}} .
$$

Equivalently,

$$
Y_{j}^{\mathrm{PPP}} / L_{j}=\left[K_{j}^{\mathrm{PPP}} / Y_{j}^{\mathrm{PPP}}\right]^{\frac{\alpha}{1-\alpha}}\left[\mathrm{TFP}_{j}\right]^{\frac{1}{1-\alpha}}
$$

Expression (14) is ready-made for development accounting. In this two-sector model, however, there is no clean demarcation of parameters into those affecting capital intensity versus those affecting aggregate TFP. Take the tax rate on investment goods. According to (10), a higher tax rate on investment goods lowers the share of labor devoted to investment goods production, and 
hence the PPP investment rate (13) and PPP capital intensity. Unless $P_{C}^{\mathrm{PPP}}$ and $P_{I}^{\mathrm{PPP}} A_{I}$ happen to be equal in the country, this higher tax rate also affects aggregate TFP. It does so by reallocating labor away from producing investment goods toward producing consumption goods. An easier way to see this is to re-express economy-wide TFP as

$$
\mathrm{TFP}_{j}=P_{C}^{\mathrm{PPP}} A_{C_{j}}\left(\frac{L_{j}-L_{I_{j}}}{L_{j}}\right)+P_{I}^{\mathrm{PPP}} A_{I_{j}} \frac{L_{I_{j}}}{L_{j}} .
$$

From this expression it is clear that reallocating labor away from investment goods production lowers aggregate TFP if $P_{C}^{\mathrm{PPP}} A_{C}<P_{I}^{\mathrm{PPP}} A_{I}$, and raises aggregate TFP if $P_{C}^{\mathrm{PPP}} A_{C}>P_{I}^{\mathrm{PPP}} A_{I}$. The use of PPP prices is crucial here. At domestic prices, the marginal product of labor is equated across sectors. At international prices this need not be so.

One can similarly show that sectoral TFPs affect both aggregate TFP and capital intensity. Consider a drop in $A_{I}$, holding $A_{C}$ fixed. This lowers aggregate TFP and the PPP investment rate. The lower PPP investment rate means lower PPP capital intensity. TFP in the investment sector matters more than the share of labor devoted to investment would suggest, as it affects capital intensity throughout the economy. That is, the effect of TFP in the investment sector is amplified through its effect on capital accumulation. ${ }^{14}$ As we shall see, poor countries appear to have not only lower $A_{C}$ and $A_{I}$ than rich countries do (as one would expect), but especially lower $A_{I}$. Their low sectoral TFPs contribute to their low aggregate TFP, and their low $A_{I} / A_{C}$ ratios contribute to their low capital intensity in PPP terms.

\footnotetext{
${ }^{14}$ Schmitz (2001) emphasizes this effect in a model with inefficient government production of investment goods.
} 
Table 1 summarizes the model's qualitative predictions. The table shows that no two exogenous variables have the same qualitative effect on all of the endogenous variables. Figure 3 illustrates the quantitative predictions of the model. ${ }^{15}$ The figure demonstrates that the forcing variables have first order effects on observables. With data on the endogenous variables, we can try to infer variation in the underlying causal variables. In the next section we do just that.

\section{Cross-Country Facts About Investment Rates and Income Levels}

The U.N. International Comparison Program (ICP) collects data on the prices of between 500 and 1500 individual goods and services in selected countries and years. The countries for which the ICP has price data in a given year are "benchmark" countries for the Penn World Table (PWT). The PWT uses the benchmark price data to convert each country's expenditures at domestic prices into expenditures at a common set of international prices. For non-benchmark country-years, prices and therefore PPP values are inferred from fitted values of price regressions run on benchmark data. Because price differences across countries are at the crux of our investigation, we concentrate on the benchmark country-years for which actual price data was collected. Benchmark data currently exists for 1970 (16 countries), 1975 (34 countries), 1980 (61 countries), 1985 (64 countries), 1990 (24 countries), and 1996 (115 countries). We focus on 1980,1985 , and 1996, the years with broad cross-sections of countries. ${ }^{16}$

\footnotetext{
${ }^{15}$ For figure 3 we set $P_{C}^{\mathrm{PPP}}=1, P_{I}^{\mathrm{PPP}}=1$, capital's share $\alpha=1 / 3$, the depreciation rate $\delta=0.07$, the annual growth of income per worker $g=0.02$, the intertemporal elasticity $\sigma=1$, and the discount factor $\beta=0.97$.

${ }^{16}$ We obtained the benchmark data from the PWT website http://pwt.econ.upenn.edu. See Summers and Heston (1991) and Heston, Summers and Aten (2002) for a fuller description of PPP methodology. We made two minor changes to the 1996 benchmark sample. First, we excluded Mongolia because its prices and quantities are zero for machinery and equipment. Second, for Antigua \& Barbuda, St. Kitts \& Nevis, and St. Lucia, we imputed missing employment as $0.5 *$ (adult equivalents). For the other benchmark countries, 0.5 is the average ratio of employment to "adult equivalents" (which the PWT defines as population over 15 plus one half of the population 15 and under).
} 
We examine simple univariate regressions of observables on country log PPP income per worker. We do not consider other regressors because we are interested simply in how the dependent variables covary with income. Our first dependent variable is the PPP fixed investment rate. Fixed investment excludes inventory investment and includes both public and private investment. We exclude inventory investment because some inventories are for consumer goods. The PWT does not contain separate data on public and private investment rates. ${ }^{17}$ Table 2 provides results of regressing the PPP fixed investment rate on PPP income per worker. In each of the three cross-sections (1980, 1985, and 1996), an additional log point of income is associated with about a five percentage point higher PPP investment rate. Across the 114 benchmark countries in 1996, the mean fixed investment rate is $17.5 \%$ and PPP income per worker varies by $4.4 \log$ points. The estimated comovement of the PPP fixed investment rate with PPP income is therefore significant relative to the mean investment rate.

Table 2 also presents results for machinery and equipment investment. Machinery and equipment are arguably the most tradable components of fixed investment (in contrast to construction). Moreover, DeLong and Summers (1991) presented evidence that the investment rate in machinery and equipment was most strongly related to growth and development. Using the PPP investment rate in machinery and equipment, the coefficients on country income remain highly significant. Although the coefficients are less than half as big as for fixed investment, so is the mean investment rate in machinery and equipment at $8.0 \%$.

We next examine the investment rate at domestic prices. Table 2 documents that, in all three years, coefficients on PPP income per worker fall by two-thirds or more when the fixed

\footnotetext{
${ }^{17}$ Pritchett (2000) argues that public investment should be distinguished from private investment, where possible, because public investment effort is less likely to create economically viable capital.
} 
investment rates are evaluated at domestic prices rather than at international prices. Eaton and Kortum (2001) and Restuccia and Urrutia (2001) also note this low correlation between domestic-price investment rates and PPP incomes across countries. ${ }^{18}$

The results in the right half of Table 2 contrast sharply with those of Levine and Renelt (1992) and Sala-i-Martin (1997), who identified the investment rate as an indomitable correlate of income. When evaluated at domestic prices, the fixed investment rate is rendered insignificant for the broadest set of countries (the 1996 sample). The most tradable portion of investment (machinery and equipment) is uncorrelated with PPP incomes in all years. Note that no conditioning variables are included in these regressions. The distinction between domestic prices and international prices is evidently crucial to the connection between investment rates and income levels. We now investigate price differences across the benchmark countries.

Many studies have noted the high relative price of investment in poor countries, and used it to help explain differences in country incomes. Examples include Jones (1994), Lee (1995), Chari et al. (1996), McGrattan and Schmitz (1999), Jovanovic and Rob (1999), and Eaton and Kortum (2001). A common theme in these papers is that the price of investment in poor countries is high relative to the price of investment prevailing in rich countries. This is thought to stem from high tariff rates on imports of investment goods and/or high tax rates on domestic production of investment goods. As the model in the previous section suggests, this hypothesis can be tested by comparing prices of investment goods in rich and poor countries after appropriate conversion into a common currency.

\footnotetext{
${ }^{18}$ Parente and Prescott (2000, p. 39) find a similar pattern for savings rates. In the PWT benchmark data, however, domestic-price savings rates are more highly correlated with PPP incomes than are domestic-price investment rates: 0.43 vs. 0.05 in $1996,0.55$ vs. 0.17 in 1985, and 0.53 vs. 0.23 in 1980. Rather than focus on savings rates, we focus on investment rates at domestic prices as the mechanism by which savings rates should affect PPP investment rates.
} 
Table 3 presents regressions of investment prices on PPP GDP per worker. We obtained these prices by converting PWT benchmark prices in national currency units into U.S. dollar prices. We did this in two different ways: using official exchange rates from the PWT (whose source is the IMF), and using black market exchange rates from the World Currency Yearbook. ${ }^{19}$ Although the official exchange rate may accurately reflect the market exchange rate in many country-years, black market premia are well-documented in some country-years. Our logic for presenting results using official exchange rates as well as black market exchange rates is as follows. First, countries may allow preferential access to the official exchange rate for trade (as opposed to purely capital account transactions). Second, countries may allow preferential access to the official exchange rate for imports of equipment and machinery (as opposed to consumer goods). Finally and most important, to the extent that a good is imported at a devalued exchange rate relative to the official one, this should show up as a high dollar price when domestic prices are converted at the official exchange rate. Using official exchange rates is, therefore, most favorable to the conventional view that investment goods are expensive in poor countries.

As documented in Table 3, neither the price of fixed investment nor the price of machinery and equipment are negatively and significantly related to PPP income per worker. This is true when prices are converted at official exchange rates as well as at black market exchange rates. In several cases investment goods actually appear more expensive in richer countries. Figure 4 illustrates the case of 1996 prices of machinery and equipment, converted into dollars at official exchange rates. As the figure reveals, the price of machinery and

\footnotetext{
${ }^{19}$ For 1996 we use black market exchange rates collected by the IMF, since the World Currency Yearbook ceased publication after 1995. We thank Carmen Reinhart and Kenneth Rogoff for providing this data. See Reinhart and Rogoff (2002) for documentation.
} 
equipment does vary across countries, especially outside the richest countries. But machinery and equipment prices look no higher in poor countries overall than in rich countries. ${ }^{20}$

PWT prices are supposed to include all taxes, tariffs, and transportation costs. The results in Table 3 are therefore a blow to the "investment barriers" explanation for the low PPP investment rates in poor countries. This explanation required a significant negative relationship between the investment price and income across countries. The lack of any significant negative relationship at official exchange rates suggests such barriers are not large. Another contributor might be lower distribution costs in poorer countries. Using input-output data, Burstein, Neves and Rebelo (2000) estimated that distribution costs accounted for $16 \%$ of the price of fixed investment in the U.S. in 1992. The positive relationship between income and investment prices at black market exchange rates could also reflect that some imports of equipment and machinery occur at official exchange rates (rather than at black market exchange rates) in poorer countries.

If the high relative price of investment in poor countries does not stem from a high price of investment, it must reflect a low price of consumption. Figure 5 shows consumption prices across countries in 1996. Table 4 provides elasticities with respect to country income. A doubling of country income goes along with $20-50 \%$ higher consumption prices. This confirms that the force behind high PPP investment rates in rich countries is high consumption prices.

Table 4 also provides separate elasticities for "nontradable" and "tradable" consumption. We classify consumption as Heston et al. (1995) do: services are nontradables (housing, medical care, purchased transportation, communications, recreation, education, and personal services), and goods are tradables (food, beverages, tobacco, clothing, footwear, fuel, house furnishings, vehicles, and personal care items). The elasticities for nontradable consumption prices with

\footnotetext{
${ }^{20}$ The results are not sensitive to omitting outliers such as Macedonia (MKD), Syria (SYR), and Gabon (GAB).
} 
respect to PPP income per worker in Table 4 are around 40-70\%. Figure 6 plots nontradable consumption prices in 1996, converted at official exchange rates. The elasticities for tradable consumption prices are markedly lower, ranging from $14 \%$ to $37 \% .^{21}$

The higher price elasticities for nontradables than for tradables fit the predictions of the Balassa-Samuelson hypothesis: nontradables are relatively cheap in poor countries. But why would tradable consumer goods be significantly cheaper in poor countries (albeit less so than nontradables)? Just as for machinery and equipment, this could reflect local distribution costs. Higher land prices and labor costs may feed into higher distribution costs in rich countries. Implicit in this explanation is that TFP in retail and wholesale trade is not commensurately higher along with wages and land prices in richer countries. Burstein et al. (2000) estimate that distribution costs represent about $40 \%$ of the average retail price of consumer goods in the U.S., and about $60 \%$ in Argentina. Interestingly, this range is roughly what would be needed to explain Table 4 if the elasticity for tradables was a weighted average of that for nontradables and a zero elasticity for truly tradable consumption goods. That is, the tradable price elasticities are about $40-60 \%$ of the nontradable price elasticities in Table 4.

A useful way to summarize our findings is in terms of the following decomposition of a country's PPP investment rate into three terms: ${ }^{22}$

$$
i_{j}^{\mathrm{PPP}} \equiv i_{j} \frac{\frac{P_{I}^{\mathrm{PPP}} I_{j}}{P_{I}^{\mathrm{PPP}} I_{j}+P_{C_{j}} C_{j}}}{i_{j}} \frac{i_{j}^{\mathrm{PPP}}}{\frac{P_{I}^{\mathrm{PPP}} I_{j}}{P_{I}^{\mathrm{PPP}} I_{j}+P_{C_{j}} C_{j}}} .
$$

\footnotetext{
${ }^{21}$ Our measure of nontradable consumption includes only private services. We obtained very similar price elasticities when we added government services to private services.

${ }^{22}$ We thank David Romer for this suggestion.
} 
The first term is the investment rate at domestic prices; this would be a country's PPP investment rate if international prices equaled its domestic prices (i.e., if $P_{I}^{\mathrm{PPP}}=P_{I}$ and $P_{C}^{\mathrm{PPP}}=P_{C}$ ). The second term in (16) captures the effect on a country's PPP investment rate of a different international than domestic price of investment $\left(P_{I}^{\mathrm{PPP}} \neq P_{I}\right.$ rather than $\left.P_{I}^{\mathrm{PPP}}=P_{I}\right)$ conditional on $P_{C}^{\mathrm{PPP}}=P_{C}$. The third term captures the effect of a different international than domestic price of consumption $\left(P_{C}^{\mathrm{PPP}} \neq P_{C}\right.$ rather than $\left.P_{C}^{\mathrm{PPP}}=P_{C}\right)$ conditional on $P_{I}^{\mathrm{PPP}} \neq P_{I}$. The three terms are one way of describing how a country's PPP investment rate is affected by, respectively, its domestic-price investment rate, its price of investment relative to the PPP price of investment, and its price of consumption relative to the PPP price of consumption.

Of course, the order in which one accounts for domestic prices deviating from PPP prices can be reversed, yielding the alternative decomposition

$$
i_{j}^{\mathrm{PPP}} \equiv i_{j} \frac{\frac{P_{I_{j}} I_{j}}{P_{I_{j}} I_{j}+P_{C}^{\mathrm{PPP}} C_{j}}}{i_{j}} \frac{i_{j}^{\mathrm{PPP}}}{\frac{P_{I_{j}} I_{j}}{P_{I_{j}} I_{j}+P_{C}^{\mathrm{PPP}} C_{j}}} .
$$

Here the middle term describes the effect on a country's PPP investment rate of a different international than domestic price of consumption $\left(P_{C}^{\mathrm{PPP}} \neq P_{C}\right)$ conditional on $P_{I}^{\mathrm{PPP}}=P_{I}$. The third term describes the effect on a country's PPP investment rate of a different international than domestic price of investment $\left(P_{I}^{\mathrm{PPP}} \neq P_{I}\right)$ conditional on $P_{C}^{\mathrm{PPP}} \neq P_{C}$. Empirically, these two orderings produce similar decompositions. In what follows we simply average the two ways of calculating investment price effects and consumption price effects.

We take logs in (16) and (17) and regress each term on log PPP GDP per worker. The elasticity for the PPP investment rate additively decomposes into three component elasticities. 
We present the results in Table 5. The elasticity of the PPP investment rate with respect to PPP GDP per worker is around 0.3 in both 1980 and 1996, and around 0.5 in 1985 . The next row indicates that at most one-third of the PPP investment rate elasticity can be attributed to richer countries having higher investment rates at domestic prices. ${ }^{23}$ The subsequent row shows that investment price differences contribute little in 1980, contribute modestly in 1985, and contribute negatively in 1996. The final row shows that, in each year, the major reason why rich countries have higher PPP investment rates is their low consumption prices.

We now ask what tax rates and productivity levels would enable the model to literally mimic the data. For each country, we calculate the tax rate on capital income $\tau_{K_{j}}$, the tax rate investment goods $\tau_{I_{j}}$, the level of TFP in the investment sector $A_{I_{j}}$, and the level of TFP in the consumption sector $A_{C_{j}}$ so that the model exactly matches the country's price of investment goods, price of consumption relative to investment, investment rate at domestic prices, and PPP income per worker. We do this for the benchmark countries in each of 1980, 1985 and 1996, respectively. We retain a healthy skepticism about this exercise because of inevitable measurement error in the data and specification error in the model.

As we did for figure 3, for this exercise we set capital's share $\alpha=1 / 3$, the depreciation rate $\delta=0.07$, the annual growth of income per worker $g=0.02$, the intertemporal elasticity $\sigma=1$, and the discount factor $\beta=0.97$. Conditional on these parameter values, there are four equations in four unknowns, so the model is just-identified. The model is recursive, so we proceed sequentially: First, we use data on investment prices in dollars to calculate the tax rate

\footnotetext{
${ }^{23}$ The investment rate elasticities in Table 5 differ from the coefficients in Table 2 because the dependent variables in the latter are investment rate levels rather than log levels.
} 
on investment goods implied by (2). We set the world price equal to the U.S. price of investment under the assumption that the U.S. tax rate on investment goods is approximately zero. Second, we use data on the price of consumption relative to investment to infer TFP in the investment sector relative to TFP in the consumer sector implied by (8). Third, we use data on the investment rate at domestic prices to solve for the tax rate on capital income implied by (10) and (11). Fourth, we use data on PPP income per worker to calculate the level of TFP in the investment sector from (10), (13), and (15). ${ }^{24}$

The implications of this exercise for tax rates and productivity levels in 1996 are as follows. The median investment tax rate is $-21 \%$ (an investment subsidy), and the interquartile range ( 25 th to 75 th percentiles) goes from a $37 \%$ subsidy to a $12 \%$ tax. The U.S., recall, was assumed to have an investment tax rate of zero. The median tax rate on capital income is $41 \%$, with an interquartile range of $19 \%$ to $60 \%$. For a number of countries (e.g., Japan and Singapore), explaining their high investment rates at domestic prices requires negative tax rates on capital income. We do not take this implication too seriously because the model abstracts from other possible sources of differing investment rates at domestic prices. Median TFP in investment goods production is $24 \%$ of the U.S. level, with an interquartile range of $11 \%$ to $61 \%$. Median implied TFP in the consumption sector is $60 \%$ of the U.S. level, with an interquartile range of $42 \%$ to $77 \%$. Note that consumption TFPs do not differ as much as investment TFPs do. As we describe next, this suggests that differences in relative TFP explain some of the differences in PPP investment rates, capital intensity, and income.

\footnotetext{
${ }^{24}$ This actually identifies $P_{I}^{\mathrm{PPP}} A_{I_{j}} / P_{C}^{\mathrm{PPP}}$ rather than $A_{I_{j}}$. The objects we report (elasticities with respect to PPP GDP per worker) are unaffected by this distinction because PPP prices do not vary across countries. We take logs and regress on log GDP per worker, so the distinction affects the constant but not the elasticities of interest.
} 
Table 6 presents elasticities of productivity levels with respect to PPP output per worker in 1980, 1985, and 1996. The first two rows show that richer countries have higher productivity in producing both investment and consumption goods - hardly surprising. More striking is that richer countries appear particularly proficient at making investment goods. The third row says countries with $1 \%$ higher PPP income tend to have 0.25 to $0.50 \%$ higher TFP in the investment sector relative to the consumption sector. In our model, this triggers a lower price of investment goods relative to consumption goods. Because investment is tradable, its price is pinned down in the world market (conditional on the tariff). Rich countries' productivity advantage in investment therefore shows up as a higher price of consumption in rich countries. This is what we estimated in Table 4. Viewed through the lens of the model, poor countries have low PPP investment rates because they have especially low productivity in their investment sectors.

The remaining rows of Table 6 present development accounting. We use (15) to calculate the level of aggregate TFP implied by sectoral TFP levels. We set $L_{I} / L$ to the U.S. level for all countries to isolate the effects of TFP differences, as opposed to differences in tax rates. We use (13) to find the PPP investment rates implied by sectoral TFPs, again assuming all countries share the U.S. $L_{I} / L$. We use (14) to obtain implications for PPP output per worker. Finally, we regress the predicted contributions on actual PPP output per worker. The results in Table 6 show that sectoral productivities appear to explain $75 \%$ or more of observed differences in income through their impact on aggregate TFP. ${ }^{25}$ More to the heart of our investigation, relative sectoral productivities appear to explain $11-23 \%$ of observed income differences through

\footnotetext{
${ }^{25}$ Given that we are omitting human capital from this accounting, our results are in line with Klenow and Rodríguez-Clare (1997) and Hall and Jones (1999). These studies estimate that TFP and human capital together explain $75-85 \%$ of income differences, with physical capital responsible for the remaining $15-25 \%$.
} 
their impact on physical capital intensity. The two contributions sum to $92-99 \%$, leaving little room for tax rates on capital income and investment to explain why countries are rich vs. poor.

To recap, poor countries do not exhibit particularly low investment rates at domestic prices. Nor do they exhibit high investment goods prices. Instead they exhibit low consumption prices. When consumption is valued at common PPP prices, the investment rates in poor countries are lower than in rich countries. Poor countries do not appear to suffer from lowsavings traps brought on by high discount rates or subsistence consumption needs. If they did, we would expect to see much lower domestic-price investment rates in poor countries. Nor do they appear to heavily tax the returns to capital. If they did we would, again, expect to see low domestic-price investment rates in poor countries. Finally, poor countries do not appear to impose high taxes and tariffs on producing and importing investment goods. If they did we would expect to see high investment good prices in poor countries. Poor countries do not appear to lack investment effort, but rather investment efficiency.

\section{Could our findings reflect measurement error in the ICP price data?}

In our model, poor countries cannot export consumer goods, their comparative advantage in production. Our model therefore ignores a way poor countries might circumvent their low efficiency in producing investment goods, namely exporting tradable consumer goods (e.g., food or clothing) and importing machinery and equipment. ${ }^{26}$ This would substitute a larger tradable consumption goods sector for an inefficient machinery and equipment sector. Empirically, most developing countries do import a significant fraction of the equipment they purchase. Eaton and

\footnotetext{
${ }^{26}$ Also, some migrants from poorer to richer countries work in nontradable consumption sectors and send remittances to their country of origin - effectively exporting nontradables to richer countries.
} 
Kortum (2001) report that the median share of equipment imports relative to domestic equipment investment was 70\% across 14 non-OECD countries in 1985.

In the appendix, we extend our model to accommodate a tradable consumption sector. Our results survive so long as poor countries have low productivity in producing tradable consumer goods tantamount to their low productivity in producing investment goods. Of course, they must have some comparative advantage in consumer tradables to explain why they are net importers of investment goods. We note that the finding in Table 4 - that poor countries have high prices of consumer tradables relative to nontradables — is consistent with their having low productivity in consumer tradables relative to nontradables.

\section{Could our findings reflect measurement error in the ICP price data?}

Classical measurement error across countries would generate precisely the opposite patterns as those in the data. Countries with overstated prices would tend to have understated incomes. Because consumption is about three times investment, countries with overstated prices of consumption relative to investment would tend to have understated incomes. And countries with overstated PPP investment rates would tend to have understated PPP incomes. Some form of non-classical measurement error would seem necessary to explain away our findings.

The U.N. Food and Agricultural Organization (FAO) provides an independent source of data on food prices in many countries, which we can compare to the food prices in the PWT benchmark data. ${ }^{27}$ In 1994, the year with FAO data for the most countries, the prices of all 190 crops rise with country income. For 48 of the 49 crops with data for at least 50 countries, the elasticity is statistically significant (the exception being wheat). Pooling all 190 crops and 
allowing for crop dummies, we estimate an elasticity with respect to country income per worker of .37 (standard error .01). This does not merely reflect agricultural price supports in OECD countries; the elasticity is $.32(.01)$ across countries outside the OECD. The elasticities would be even higher using black market exchange rates. FAO data on food prices clearly support the conclusion we reach from the PWT data: food prices are decidedly higher in richer countries.

One could argue that crops are relatively homogeneous, whereas other goods and services can differ substantially in quality across countries. This raises the issue: How closely does the ICP come to pricing comparable quality items in different benchmark countries? This is the stated goal of the ICP, so there is some hope that comparable quality items are priced even if the average quality of items sold is higher in richer countries. For example, the ICP compares the prices of particular car models across countries (in 1975, Ford Escort 1100s, BMW 1602s, Chevy Camaros, etc.). And it compares houses of the same size, vintage (year built), and facilities (electricity, water, bath, central heating).

The ICP's goal notwithstanding, it may inadvertently price higher quality items in richer countries. Properly adjusted for quality differences, the price of investment goods might fall (and the price of consumption no longer rise) with country income. Trade barriers to importing equipment could be higher in poor countries than ICP prices suggest. Eaton and Kortum (2001) take this view. If they are right, then ICP data understate differences in PPP income per worker across countries. According to Table 4, an unmeasured quality elasticity of 0.25 or more would be needed to keep quality-adjusted consumption prices from rising with PPP income. With an

\footnotetext{
${ }^{27}$ The data can be downloaded from http://apps.fao.org/page/collections? subset=agriculture. The FAO data provides prices in local currency. We convert to dollar prices using IMF official exchange rates.
} 
elasticity of unmeasured quality of 0.25 with respect to measured PPP income, true purchasing power would vary by a factor of 40 rather than 32 across the richest and poorest economies. ${ }^{28}$ Might unmeasured quality differences be larger for consumption (e.g., education and health care) than for investment? If so, then measurement error would contribute both to the high measured price of consumption and to the high measured PPP investment rates in rich countries. Adding in the unmeasured PPP consumption in rich countries would lower their PPP investment rates. The correlation between PPP investment rates and PPP incomes would partially reflect measurement error rather than reality. This would undercut a BalassaSamuelson interpretation of the data, to be sure, but would also undercut tax and tariff explanations of the investment-income correlation. It would mean differences in PPP income are larger and differences in PPP capital intensity smaller than the PWT data suggest. If true, we have even more variation in income and TFP to explain and understand.

Pritchett (2000) argues for a form of measurement error going the other way. He maintains that public investment is often high and inefficient in poor countries, so that effective investment rates covary more strongly with PPP incomes than do measured PPP investment rates. We view his story as very much in the spirit of ours, namely that poor countries suffer more from a lack of investment efficiency than a lack of investment effort. ${ }^{29}$

\footnotetext{
${ }^{28}$ Hummels and Klenow (2002) estimate an elasticity of export quality with respect to PPP income of about 0.11 across 121 countries in 1995. If this elasticity is representative of country expenditures, then quality does not vary enough with income to explain our findings (even if no quality differences are controlled for by the ICP).

${ }^{29}$ A related hypothesis is that the quality of investment projects undertaken is lower in poor countries, say because of financial underdevelopment. Imrohoroglu and Kumar (2003) and Erosa and Hidalgo Cabrillana (2003) advance this story as a contributor to the low TFP in poor countries.
} 


\section{Conclusion}

The higher investment rate in rich countries than in poor countries is arguably the most consistent finding in the empirical growth and development literature. We find that richer countries have a significantly higher investment rate in PPP terms, but not in domestic price terms. This pinpoints the low price of investment relative to consumption in rich countries as the main force behind their high PPP investment rates. We find no lower investment prices but notably higher consumption prices in rich economies.

Subject to caveats about possible measurement error in the PWT data, we conclude that low PPP investment rates in poor countries are not due to low savings rates or high tax rates on capital or investment. We instead trace the low investment rates in poor countries to their low TFP in producing investment goods relative to consumption. Consumption is cheap in poor countries, making investment expensive and lowering PPP investment rates.

To the extent consumption is less tradable than investment, our findings are consistent with the Balassa-Samuelson hypothesis. This hypothesis holds that productivity in nontradables (e.g., haircuts, taxicabs, retail trade) rises less with country income than does productivity in tradables. The Balassa-Samuelson hypothesis begs the question of why this should be so. We offer two brief comments: First and foremost, tradables might have inherently greater capacity for productivity variation than services do, say because the latter are labor-intensive and hard to mechanize. This explanation is often given for why tradables productivity grows faster than services productivity over time. Second, by increasing the scale of the market, tradability may raise the return to innovations. This could lead to faster innovation for tradables. A faster pace of innovation, in turn, could produce greater differences in productivity. This is a common feature of models with gradual technology diffusion, such as Howitt (2000). 


\section{Figure 1: Investment Rates at International Prices}

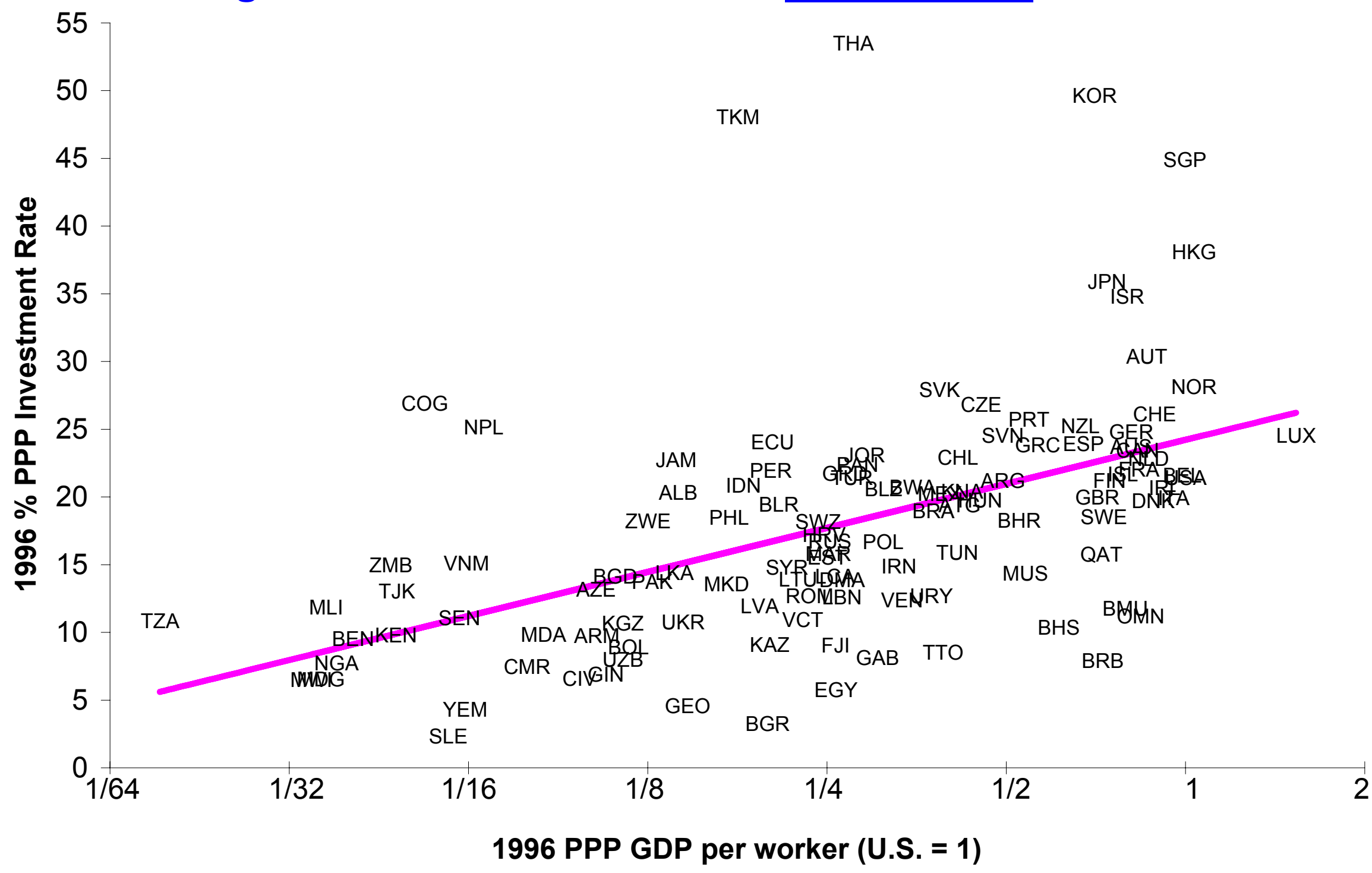


Figure 2: Investment Rates at Domestic Prices

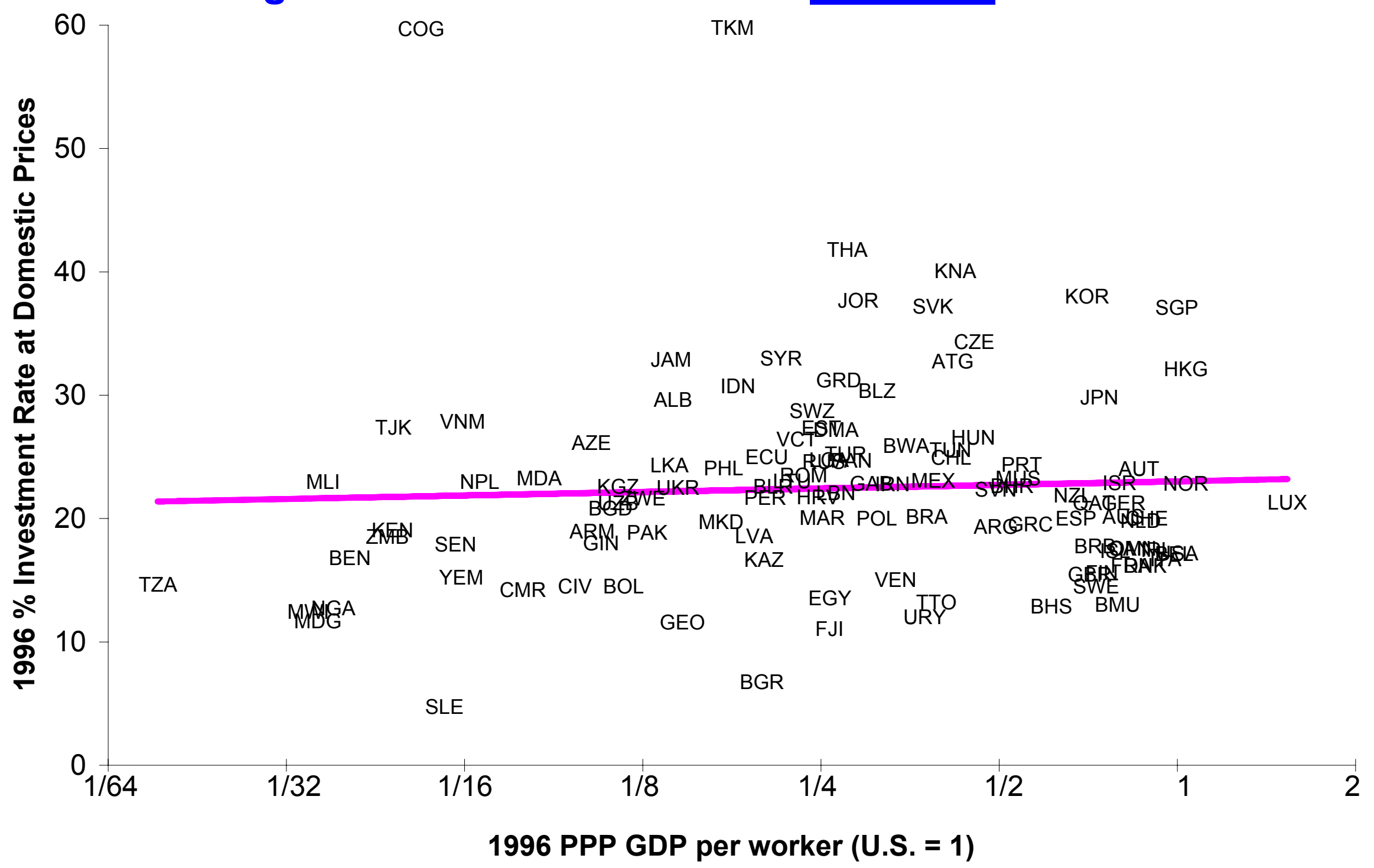


Figure 3
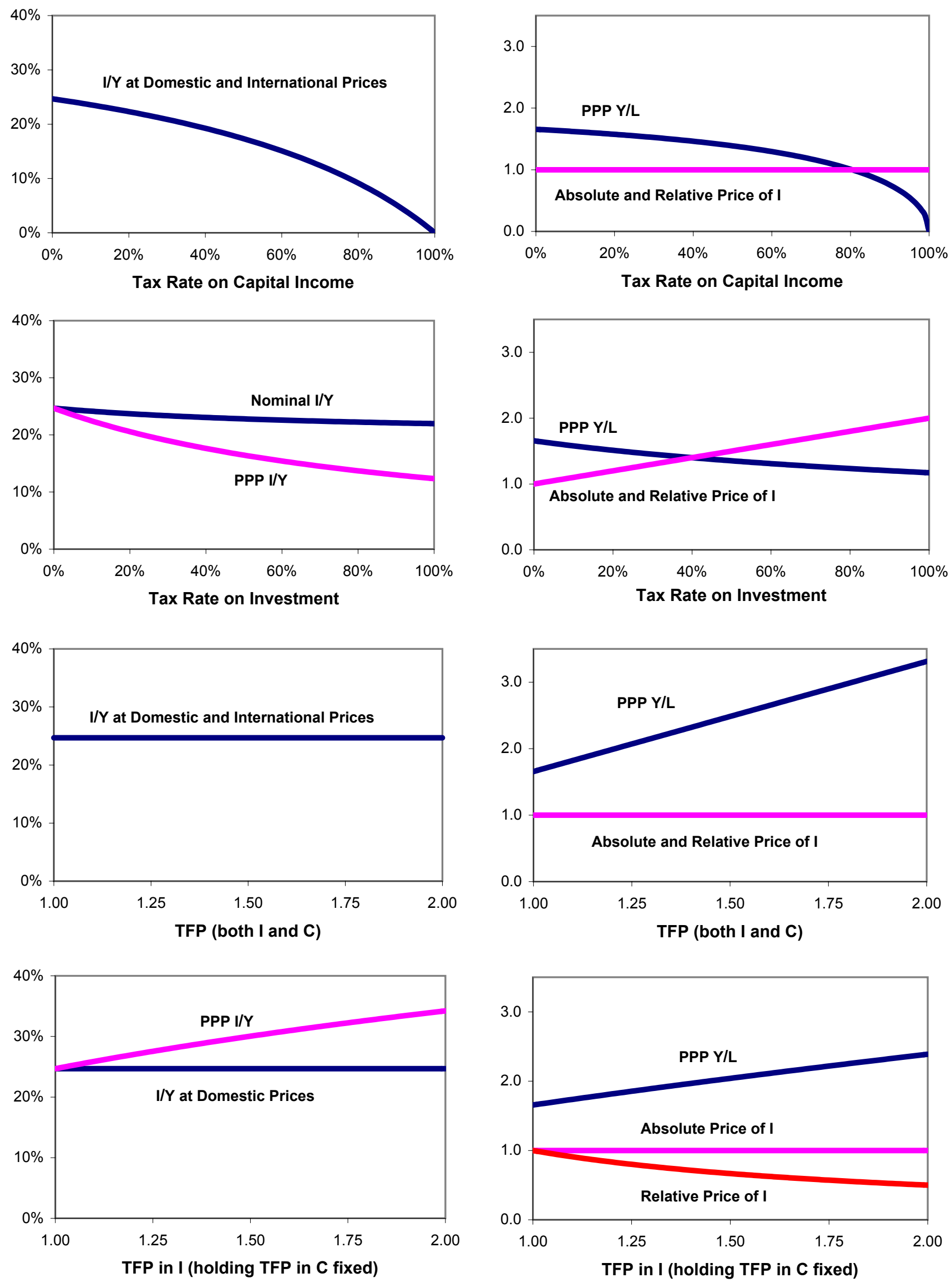


\section{Figure 4: 1996 Price of Machinery and Equipment}

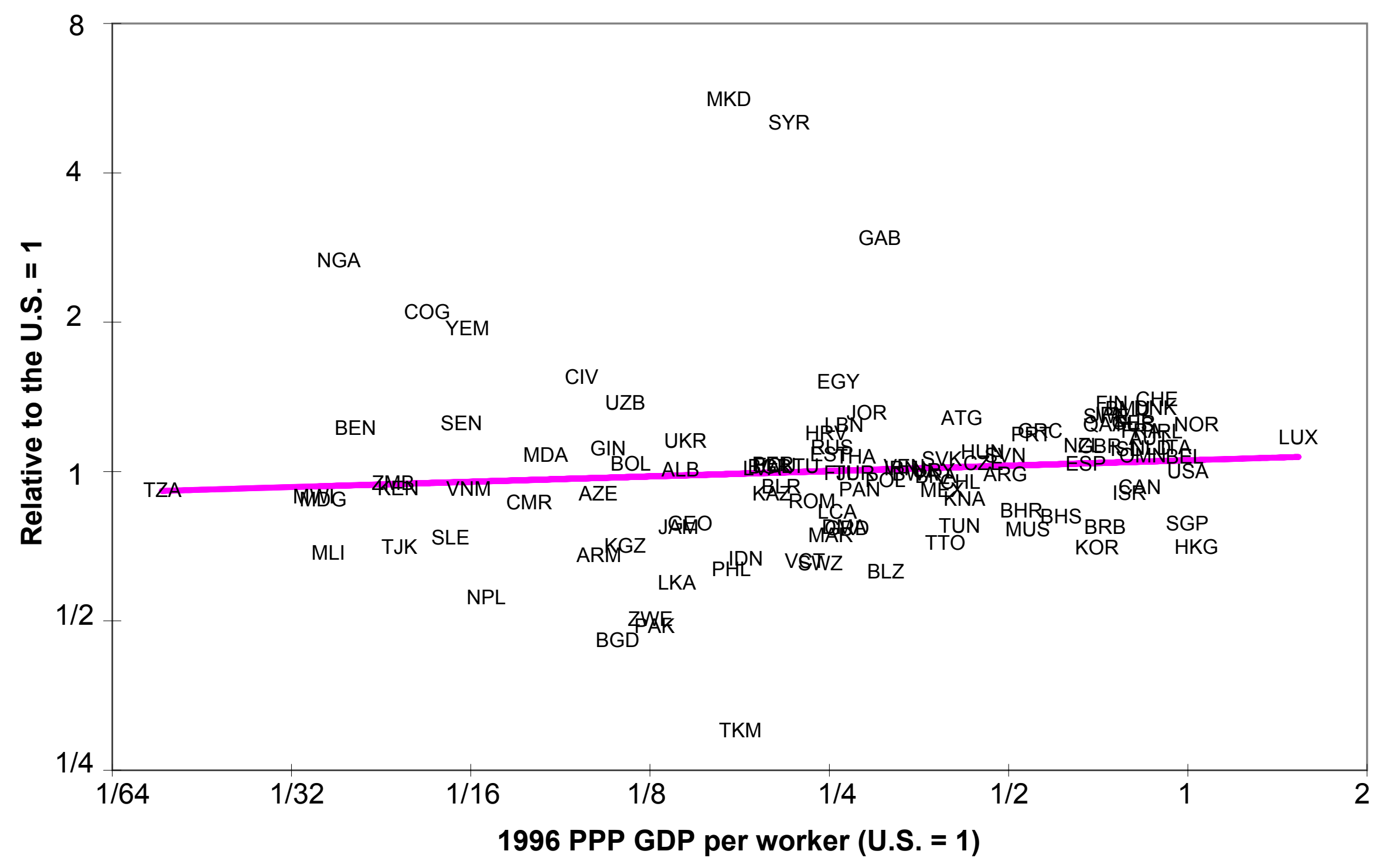




\section{Figure 5: 1996 Price of Consumption}

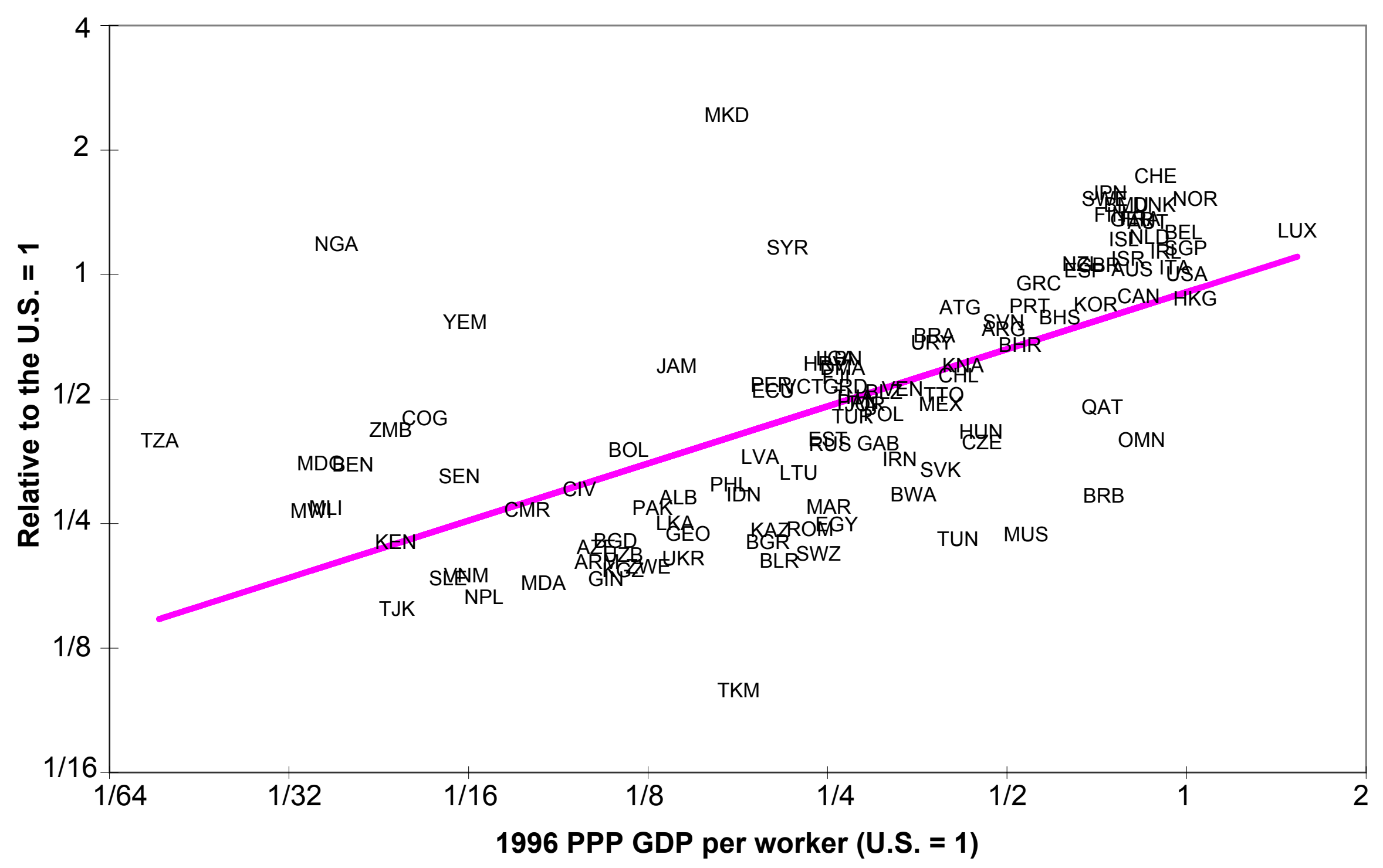




\section{Figure 6: 1996 Price of Nontradable Consumption}

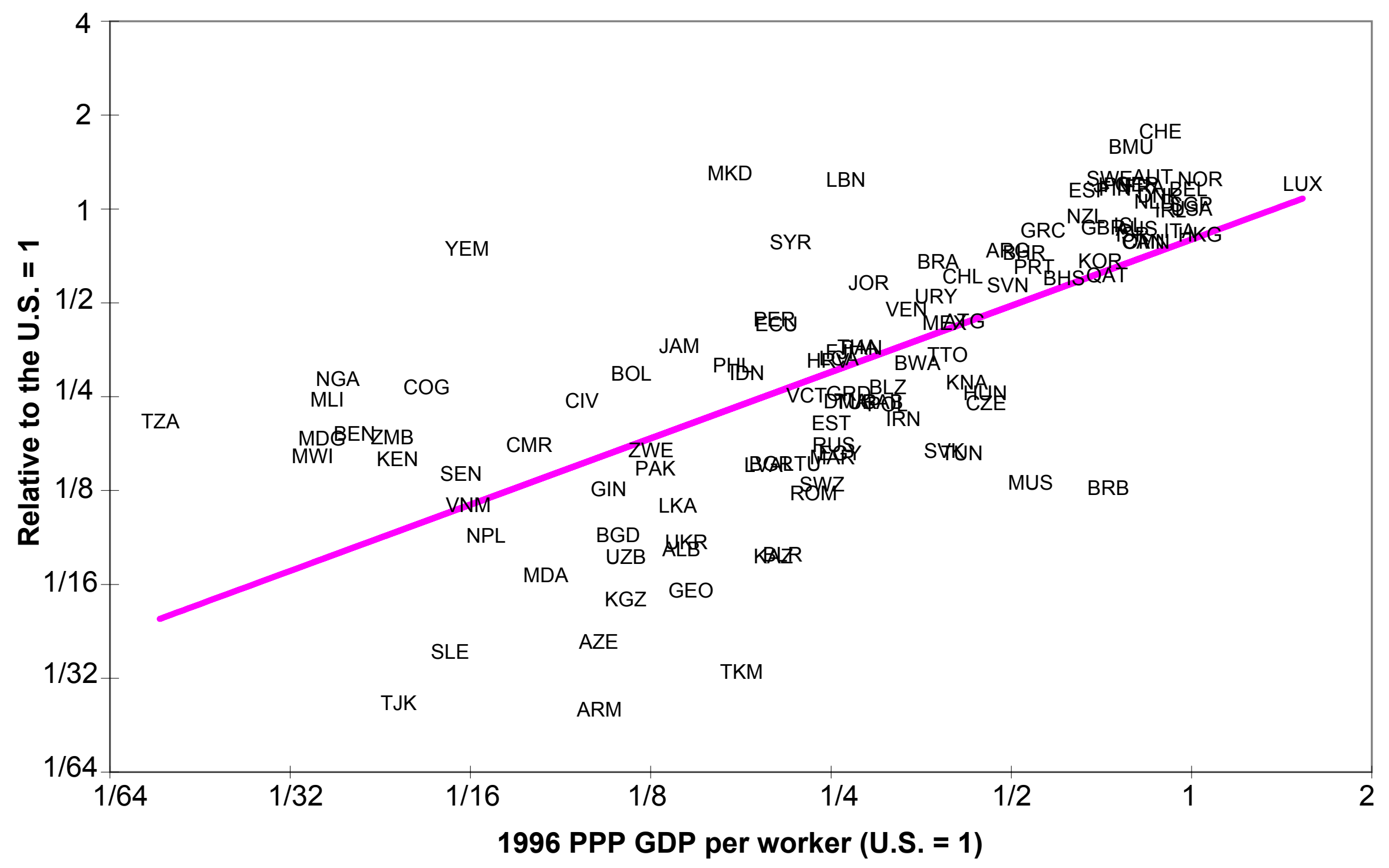




\section{Table 1}

\section{Comparative Steady States in the Model}

\begin{tabular}{|c|c|c|c|c|c|}
\hline $\begin{array}{c}\text { Endogenous } \rightarrow \\
\text { Exogenous } \downarrow\end{array}$ & $i$ & $i^{\text {PPP }}$ & $P_{I}$ & $P_{I} / P_{C}$ & $Y / L$ \\
\hline$\tau_{K}$ & 一 & - & & & 一 \\
\hline$\tau_{I}$ & - & - & + & + & - \\
\hline $\boldsymbol{A}_{\boldsymbol{I}}$ and $\boldsymbol{A}_{\boldsymbol{C}}$ & & & & & + \\
\hline $\boldsymbol{A}_{\boldsymbol{I}}\left(\boldsymbol{A}_{\boldsymbol{C}}\right.$ fixed $)$ & & + & & - & + \\
\hline
\end{tabular}

Note: Blank entries denote independence between the variables.

$\boldsymbol{i}=$ the investment rate at domestic prices.

$\boldsymbol{i}^{\mathbf{P P P}}=$ the investment rate at international prices.

$\boldsymbol{P}_{\boldsymbol{I}}=$ the domestic price of investment. $\boldsymbol{P}_{\boldsymbol{C}}=$ the domestic price of consumption.

$\boldsymbol{Y} / \boldsymbol{L}=$ PPP GDP per worker. $\tau_{\boldsymbol{K}}=$ the tax rate on capital income.

$\tau_{\boldsymbol{I}}=$ the tax rate on producing and importing investment goods.

$\boldsymbol{A}_{\boldsymbol{I}}=$ investment sector productivity. $\boldsymbol{A}_{\boldsymbol{C}}=$ consumption sector productivity. 
Table 2

PPP Investment Rates vs. Investment Rates at Domestic Prices

Independent Variable $=\log$ PPP GDP per worker

\begin{tabular}{|c|c|c|c|c|c|c|}
\hline \multirow[b]{2}{*}{ Dependent Variable } & \multicolumn{3}{|c|}{ PPP Investment Rates } & \multicolumn{3}{|c|}{ Investment Rates at Domestic Prices } \\
\hline & 1980 & 1985 & 1996 & 1980 & 1985 & 1996 \\
\hline \multirow[t]{2}{*}{$\begin{array}{c}\text { Fixed } \\
\text { Investment }\end{array}$} & $\begin{array}{c}\mathbf{4 . 6 4} \\
(0.75)\end{array}$ & $\begin{array}{c}\mathbf{5 . 7 4} \\
(0.46)\end{array}$ & $\begin{array}{c}4.62 \\
(0.74)\end{array}$ & $\begin{array}{c}\mathbf{1 . 5 1} \\
(0.71)\end{array}$ & $\begin{array}{c}\mathbf{1 . 5 9} \\
(0.54)\end{array}$ & $\begin{array}{c}0.58 \\
(0.73)\end{array}$ \\
\hline & $\mathrm{R}^{2}=.32$ & $\mathrm{R}^{2}=.60$ & $\mathrm{R}^{2}=.26$ & $\mathrm{R}^{2}=.06$ & $\mathrm{R}^{2}=.10$ & $\mathrm{R}^{2}=.01$ \\
\hline \multirow[t]{2}{*}{$\begin{array}{c}\text { Machinery } \\
\text { and Equipment }\end{array}$} & $\begin{array}{c}\mathbf{1 . 2 3} \\
(0.35)\end{array}$ & $\begin{array}{c}\mathbf{1 . 8 9} \\
(0.20)\end{array}$ & $\begin{array}{c}\mathbf{2 . 4 0} \\
(0.44)\end{array}$ & $\begin{array}{c}0.26 \\
(0.28)\end{array}$ & $\begin{array}{c}0.45 \\
(0.25)\end{array}$ & $\begin{array}{l}-0.43 \\
(0.59)\end{array}$ \\
\hline & $\mathrm{R}^{2}=.14$ & $\mathrm{R}^{2}=.50$ & $\mathrm{R}^{2}=.21$ & $\mathrm{R}^{2}=.01$ & $\mathrm{R}^{2}=.03$ & $\mathrm{R}^{2}=.00$ \\
\hline \# of benchmark countries & 61 & 64 & 114 & 61 & 64 & 114 \\
\hline
\end{tabular}

Notes: Each entry is a coefficient from a single regression. Robust standard errors are in parentheses. Bold coefficients are significant at the 5\% level. Fixed Investment includes equipment and structures, and excludes inventory investment. Machinery and Equipment includes both electrical machinery and nonelectrical machinery. 


\section{Table 3}

The Price of Investment Goods

Independent Variable $=\log$ PPP GDP per worker

\begin{tabular}{ccccccc}
\hline & \multicolumn{3}{c}{ At Official Exchange Rates } & \multicolumn{3}{c}{ At Black Market Exchange Rates } \\
Dependent Variable & $\mathbf{1 9 8 0}$ & $\mathbf{1 9 8 5}$ & $\mathbf{1 9 9 6}$ & $\mathbf{1 9 8 0}$ & $\mathbf{1 9 8 5}$ & $\mathbf{1 9 9 6}$ \\
\hline $\begin{array}{c}\text { Fixed } \\
\text { Investment }\end{array}$ & .024 & -.038 & $\mathbf{. 1 8 3}$ & $\mathbf{. 1 9 0}$ & .096 & $\mathbf{. 2 4 5}$ \\
& $(.049)$ & $(.048)$ & $(.045)$ & $(.053)$ & $(.050)$ & $(.047)$ \\
& $\mathrm{R}^{2}=.00$ & $\mathrm{R}^{2}=.01$ & $\mathrm{R}^{2}=.07$ & $\mathrm{R}^{2}=.14$ & $\mathrm{R}^{2}=.03$ & $\mathrm{R}^{2}=.19$ \\
$\begin{array}{c}\text { Machinery } \\
\text { and Equipment }\end{array}$ & .014 & -.058 & .052 & $\mathbf{. 1 8 0}$ & .076 & $\mathbf{. 1 1 3}$ \\
& $(.041)$ & $(.035)$ & $(.033)$ & $(.058)$ & $(.048)$ & $(.035)$ \\
& $\mathrm{R}^{2}=.00$ & $\mathrm{R}^{2}=.03$ & $\mathrm{R}^{2}=.02$ & $\mathrm{R}^{2}=.14$ & $\mathrm{R}^{2}=.02$ & $\mathrm{R}^{2}=0.08$ \\
& & & & & & \\
\# of benchmark countries & 61 & 64 & 114 & 61 & 64 & 114 \\
\hline
\end{tabular}

Note: Prices are in dollars (converted from national currencies at official or black market exchange rates.) 
Table 4

\section{The Price of Consumption}

\begin{tabular}{|c|c|c|c|c|c|c|}
\hline \multirow{2}{*}{$\begin{array}{c}\text { Dependent Variable } \\
\downarrow \\
\end{array}$} & \multicolumn{3}{|c|}{ At Official Exchange Rates } & \multicolumn{3}{|c|}{ At Black Market Exchange Rates } \\
\hline & 1980 & 1985 & 1996 & 1980 & 1985 & 1996 \\
\hline \multirow[t]{2}{*}{$\begin{array}{c}\text { All } \\
\text { Consumption }\end{array}$} & $\begin{array}{l}.221 \\
(.053)\end{array}$ & $\begin{array}{l}.286 \\
(.049)\end{array}$ & $\begin{array}{l}. \mathbf{4 4 5} \\
(.048)\end{array}$ & $\begin{array}{l}. \mathbf{3 8 0} \\
(.049)\end{array}$ & $\begin{array}{l}.415 \\
(.038)\end{array}$ & $\begin{array}{l}\mathbf{. 5 0 7} \\
(.052)\end{array}$ \\
\hline & $\mathrm{R}^{2}=.25$ & $\mathrm{R}^{2}=.41$ & $\mathrm{R}^{2}=.43$ & $\mathrm{R}^{2}=.43$ & $\mathrm{R}^{2}=.52$ & $\mathrm{R}^{2}=.45$ \\
\hline \multirow[t]{2}{*}{$\begin{array}{l}\text { Nontradable } \\
\text { Consumption }\end{array}$} & $\begin{array}{l}.377 \\
(.064)\end{array}$ & $\begin{array}{l}.415 \\
(.050)\end{array}$ & $\begin{array}{l}.660 \\
(.059)\end{array}$ & $\begin{array}{l}.542 \\
(.062)\end{array}$ & $\begin{array}{l}.540 \\
(.050)\end{array}$ & $\begin{array}{l}.721 \\
(.065)\end{array}$ \\
\hline & $\mathrm{R}^{2}=.38$ & $\mathrm{R}^{2}=.51$ & $\mathrm{R}^{2}=.48$ & $\mathrm{R}^{2}=.49$ & $\mathrm{R}^{2}=.53$ & $\mathrm{R}^{2}=.52$ \\
\hline \multirow[t]{2}{*}{$\begin{array}{c}\text { Tradable } \\
\text { Consumption }\end{array}$} & $\begin{array}{l}.141 \\
(.047)\end{array}$ & $\begin{array}{l}.223 \\
(.049)\end{array}$ & $\begin{array}{l}. \mathbf{3 1 0} \\
(.040)\end{array}$ & $\begin{array}{l}. \mathbf{3 0 7} \\
(.045)\end{array}$ & $\begin{array}{l}. \mathbf{3 5 7} \\
(.034)\end{array}$ & $\begin{array}{l}.372 \\
(.041)\end{array}$ \\
\hline & $\mathrm{R}^{2}=.15$ & $\mathrm{R}^{2}=.33$ & $\mathrm{R}^{2}=.35$ & $\mathrm{R}^{2}=.37$ & $\mathrm{R}^{2}=.41$ & $\mathrm{R}^{2}=.42$ \\
\hline \# of benchmark countries & 61 & 64 & 114 & 61 & 64 & 114 \\
\hline
\end{tabular}

Notes: The independent variable is always log PPP GDP per worker. Nontradables are services, tradables are goods. 


\section{Table 5}

\section{Decomposing PPP Investment Rates}

$$
\text { Independent Variable }=\text { PPP GDP per worker }
$$

\begin{tabular}{|c|c|c|c|}
\hline Dependent Variable & 1980 & 1985 & 1996 \\
\hline PPP investment rate & $\begin{array}{c}.296 \\
(.045)\end{array}$ & $\begin{array}{c}\mathbf{. 5 1 4} \\
(.056)\end{array}$ & $\begin{array}{c}.325 \\
(.043)\end{array}$ \\
\hline investment rate at domestic prices & $\begin{array}{c}. \mathbf{0 8 5} \\
(.031)\end{array}$ & $\begin{array}{c}\mathbf{. 0 8 8} \\
(.036)\end{array}$ & $\begin{array}{c}.067 \\
(.033)\end{array}$ \\
\hline investment price term & $\begin{array}{c}.006 \\
(.036)\end{array}$ & $\begin{array}{c}\mathbf{. 1 0 7} \\
(.046)\end{array}$ & $\begin{array}{l}-.205 \\
(.073)\end{array}$ \\
\hline consumption price term & $\begin{array}{c}.204 \\
(.035)\end{array}$ & $\begin{array}{c}. \mathbf{3 1 9} \\
(.040)\end{array}$ & $\begin{array}{c}.463 \\
(.074)\end{array}$ \\
\hline \# of benchmark countries & 61 & 64 & 114 \\
\hline
\end{tabular}

Notes: All variables are in log terms. Each entry is a coefficient from a single regression. Robust standard errors are in parentheses. Bold coefficients are significant at the 5\% level. Investment refers to fixed investment. See equations (16) through (17) and surrounding text for description of the investment price and consumption price terms. As implied by (16) and (17), the first row decomposes into the other three rows. This Table uses prices converted into dollars at official exchange rates. 


\section{Table 6}

\section{Productivity Levels and Income Differences}

(Entries are elasticities with respect to PPP $Y / L$ )

\begin{tabular}{|c|c|c|c|}
\hline & 1980 & 1985 & 1996 \\
\hline $\boldsymbol{A}_{I}$ & $\begin{array}{l}.778 \\
(.034)\end{array}$ & $\begin{array}{c}.824 \\
(.037)\end{array}$ & $\begin{array}{c}.965 \\
(.036)\end{array}$ \\
\hline$A_{C}$ & $\begin{array}{l}.529 \\
(.017)\end{array}$ & $\begin{array}{c}.452 \\
(.020)\end{array}$ & $\begin{array}{l}.465 \\
(.017)\end{array}$ \\
\hline $\boldsymbol{A}_{I} / \boldsymbol{A}_{C}$ & $\begin{array}{l}.249 \\
(.045)\end{array}$ & $\begin{array}{c}.372 \\
(.051)\end{array}$ & $\begin{array}{l}.500 \\
(.049)\end{array}$ \\
\hline $\begin{array}{l}\text { Contribution } \\
\text { through TFP }\end{array}$ & $\begin{array}{l}.849 \\
(.021)\end{array}$ & $\begin{array}{l}.761 \\
(.023)\end{array}$ & $\begin{array}{r}.768 \\
(.021)\end{array}$ \\
\hline $\begin{array}{l}\text { Contribution } \\
\text { through } K / Y\end{array}$ & $\begin{array}{l}. \mathbf{1 0 6} \\
(.019)\end{array}$ & $\begin{array}{l}. \mathbf{1 5 8} \\
(.022)\end{array}$ & $\begin{array}{l}.226 \\
(.022)\end{array}$ \\
\hline \# of countries & 61 & 64 & 114 \\
\hline
\end{tabular}

Notes: All variables are in logs. $\boldsymbol{A}_{\boldsymbol{I}}=$ productivity in the investment sector. $\boldsymbol{A}_{\boldsymbol{C}}=$ productivity in the consumption sector. See equation (15) for the definition of aggregate TFP. See equation (14) for the contributions of TFP and $K / Y$. Here TFP and $K / Y$ incorporate country-specific $\boldsymbol{A}_{\boldsymbol{I}}$ and $\boldsymbol{A}_{\boldsymbol{C}}$ only; each country is assumed to have the same tax rates (and hence the same $L_{I} / L$ ) as the U.S.. Where prices are used for the calculations in this Table, they are in dollars converted at official exchange rates. 


\section{Appendix}

\section{1: Tradable consumption goods}

Here we modify the model to allow for two types of consumption goods: tradable and non-tradable. With this modification, countries that have a comparative advantage in producing tradable consumption goods can export these goods in exchange for machinery and equipment. Specifically, country $j$ will export tradable consumption goods and import investment goods if

$$
\frac{A_{C T_{j}}}{A_{I_{j}}}>\frac{P_{I}^{\text {world }}}{P_{C T}^{\text {world }}} \equiv p .
$$

A country will export investment goods in exchange for tradable consumer goods if the inequality goes the other way. $A_{C T_{j}}$ is the exogenous index of productivity in the tradable consumption goods sector and $p$ is the world price of investment goods relative to the world price of tradable consumer goods. We will assume that countries are small enough such that they are completely specialized either in tradable consumption or in investment goods (although all countries will produce non-tradable consumption goods).

We begin by showing the key endogenous variables for countries with a comparative advantage in investment goods. From the firm's first order conditions, one can show that the relative price of nontradable consumption is

$$
\frac{P_{C N_{j}}}{P_{I_{j}}}=\frac{A_{I_{j}}}{A_{C N_{j}}\left(1+\tau_{I_{j}}\right)}
$$

Equation (1.2) is exactly the same as (8). Next, we determine the share of factor inputs that are devoted to domestic investment. In this model, equation (10) pins down the share of labor used to produce investment goods channeled towards domestic investment, rather than the share of labor devoted to the investment goods sector: 


$$
L_{I_{j}}^{D} / L_{j} \equiv\left(L_{I_{j}} / L_{j}\right)\left(I_{j}^{D} / I_{j}\right)=\frac{(g+\delta) \alpha\left(1-\tau_{K_{j}}\right)}{\left(1+\tau_{I_{j}}\right)\left[(1+g)^{l / \sigma} / \beta-1+\delta\left(1-\tau_{K_{j}}\right)\right]}
$$

Here $I_{j}^{D}$ denotes the flow of real investment and $L_{I_{j}}^{D}$ the labor used to produce $I_{j}^{D}$. The investment rate at domestic prices is given by equation (11), with $L_{I_{j}} / L_{j}$ replaced by $L_{I_{j}}^{D} / L_{j}$ :

$$
i_{j}=\frac{\left(1+\tau_{I_{j}}\right) L_{I_{j}}^{D} / L_{j}}{1+\tau_{I_{j}} L_{I_{j}}^{D} / L_{j}} .
$$

In turn, the PPP investment rate is given by

$$
i_{j}^{P P P}=\frac{P_{I}^{P P P} A_{I_{j}} L_{I_{j}}^{D} / L_{j}}{\left(\left(P_{I}^{P P P} / P_{C T}^{P P P}\right) / p-1\right) A_{I_{j}} L_{I_{j}}^{D} / L_{j}+P_{C T}^{P P P} p A_{I_{j}} L_{I_{j}} / L_{j}+P_{C N}^{P P P} A_{C N_{j}}\left(1-L_{I_{j}} / L_{j}\right)} .
$$

The total share of labor employed in the investment goods sector is

$$
L_{I_{j}} / L_{j}=L_{I_{j}}^{D} / L_{j}+\gamma_{j}\left(1-L_{I_{j}}^{D} / L_{j}\right)
$$

where $\gamma_{j} \equiv \frac{P_{C T_{j}} C_{T_{j}}}{P_{C T_{j}} C_{T_{j}}+P_{C N_{j}} C_{N_{j}}}$ is the consumption share of tradables. Comparing (1.5) and (1.6) with (13), one can see that $p$ and $\gamma_{j}$ now potentially affect the PPP investment rate (although not the investment rate at domestic prices). However, since $p$ is constant across countries, $\gamma_{j}$ is the only additional variable that can contribute to cross-country differences in PPP investment rates.

In the benchmark data, $\gamma_{j}$ tends to be lower in richer countries: nontradable services are a higher fraction of consumption in richer countries. A lower share of tradables in consumption should boost the PPP investment rate to the extent $P_{C T}^{P P P} p A_{I_{j}}>P_{C N}^{P P P} A_{C N_{j}}$. In section 4 we argued that $A_{I_{j}} / A_{C N_{j}}$ tends to rise with PPP income, suggesting this inequality will generally prevail for richer countries. Thus, across rich countries with a comparative advantage in investment goods, $\gamma_{j}$ should contribute to a higher PPP investment rate in richer countries. 
Now we turn to countries with a comparative advantage in producing tradable consumption goods. The relative price of non-tradable consumption goods is

$$
\frac{P_{C N_{j}}}{P_{I_{j}}}=\frac{A_{C T_{j}}}{A_{C N_{j}}\left(1+\tau_{I_{j}}\right) p}
$$

Equation (1.7) indicates that an alternative explanation for the low price of non-tradable consumption goods in poor countries is that they are relatively inefficient in producing tradable consumer goods. Equation (10) pins down the share of labor devoted to production of exports of tradable consumer goods

$$
L_{C T_{j}}^{X} / L_{j} \equiv\left(L_{C T_{j}} / L_{j}\right)\left(C_{T_{j}}^{X} / C_{T_{j}}\right)=\frac{(g+\delta) \alpha\left(1-\tau_{K_{j}}\right)}{\left(1+\tau_{I_{j}}\right)\left[(1+g)^{1 / \sigma} / \beta-1+\delta\left(1-\tau_{K_{j}}\right)\right]} .
$$

Here, $C_{T_{j}}^{X}$ denotes the exports of tradable consumer goods and $L_{C T_{j}}^{X}$ the labor used to produce these exports. The investment rate at domestic prices is

$$
i_{j}=\frac{\left(1+\tau_{I_{j}}\right) L_{C T_{j}}^{X} / L_{j}}{1+\tau_{I_{j}} L_{C T_{j}}^{X} / L_{j}}
$$

The PPP investment rate is given by

(1.10) $i_{j}^{P P P}=\frac{\left(P_{I}^{P P P} / p\right) A_{C T_{j}} L_{C T_{j}}^{X} / L_{j}}{\left(\left(P_{I}^{P P P} / P_{C T}^{P P P}\right) / p-1\right) A_{C T_{j}} L_{C T_{j}}^{X} / L_{j}+P_{C T}^{P P P} A_{C T_{j}} L_{C T_{j}} / L_{j}+P_{C N}^{P P P} A_{C N_{j}}\left(1-L_{C T_{j}} / L_{j}\right)}$

Again, the only additional variable that can potentially explain the correlation of PPP investment rates with PPP incomes is the share of tradables in consumption, $\gamma_{j}$.

As noted, $\gamma_{j}$ tends to be higher in poorer countries. A higher share of tradables in consumption should lower the PPP investment rate to the extent $P_{C T}^{P P P} A_{C T_{j}}>P_{C N}^{P P P} A_{C N_{j}}$. In section 
4 we reported evidence suggesting that $A_{C T_{j}} / A_{C N_{j}}$ rises with PPP income, suggesting the inequality will tend to go the wrong way for poorer countries. Therefore, across poorer countries with a comparative advantage in tradable consumer goods, $\gamma_{j}$ should contribute to a lower PPP investment rate in richer countries, the opposite of the pattern in the data.

Putting the two cases together, we see that tradable consumer goods would contribute a U-shape to PPP investment rates across poorer vs. richer economies. Generalizing the model in this way would not help explain the uniform tendency of higher PPP investment rates along with higher PPP incomes.

\section{2: Differing Sectoral Factor Shares}

Although capital shares appear roughly equal across U.S. consumption and investment sectors, here we sketch the implications of a higher capital share in the investment sector. In place of (5) and (6) we consider

$$
\begin{gathered}
C_{j}=A_{C_{j}} K_{C_{j}}^{\alpha_{C}} L_{C_{j}}^{1-\alpha_{C}} \\
I_{j}=A_{I_{j}} K_{I_{j}}^{\alpha_{I}} L_{I_{j}}^{1-\alpha_{I}}
\end{gathered}
$$

This alters the fundamental equations as follows. In place of (10) and (13) we have

(2.3) $\frac{L_{I_{j}}}{L_{j}}=\frac{(g+\delta) \alpha_{C}\left(1-\tau_{K_{j}}\right)\left(1-\alpha_{I}\right)}{\left(1+\tau_{I_{j}}\right)\left[(1+g)^{1 / \sigma} / \beta-1+\delta\left(1-\tau_{K_{j}}\right)\right]\left(1-\alpha_{C}\right)+(g+\delta)\left(1-\tau_{K_{j}}\right)\left[\left(1-\alpha_{I}\right) \alpha_{C}-\left(1-\alpha_{C}\right) \alpha_{I}\right]}$.

and

$$
i_{j}^{P P P}=\frac{P_{I}^{P P P} A_{I_{j}} L_{I_{j}} / L_{j}}{P_{I}^{P P P} A_{I_{j}} L_{I_{j}} / L_{j}+P_{C}^{P P P} A_{C_{j}}\left(1-L_{I_{j}} / L_{j}\right)\left\{\frac{(1+g)^{1 / \sigma} / \beta-1+\delta\left(1-\tau_{K_{j}}\right)}{\left(1-\tau_{K j}\right) \alpha_{I} A_{I_{j}}}\right\}^{\frac{\alpha_{I}-\alpha_{C}}{1-\alpha_{I}}}} .
$$


The price of investment still satisfies (2), so the implied tax rate on investment is unaffected by $\alpha_{I} \neq \alpha_{C}$. The expression for the investment rate at domestic prices remains (11), but it is affected by $\alpha_{I} \neq \alpha_{C}$ through $L_{I_{j}} / L_{j}$. As shown by (11) and (2.3), however, $\tau_{I}$ and $\tau_{K}$ remain the only variables capable of generating country differences in domestic-price investment rates. Given that the domestic-price investment rate does not relate significantly to PPP income across countries, the capital income tax rate cannot relate significantly to country income. In sum, our conclusion that sectoral productivities (rather than tax rates) explain most of the variation in PPP investment rates holds even if we allow $\alpha_{I} \neq \alpha_{C}$.

\section{3: Differing Sectoral Productivity Growth Rates}

Here we relax the assumption that TFP grows at the same rate in the two sectors, and suppose instead that TFP grows at a constant rate $g_{C}$ in the nontradable consumer goods sector and $g_{I}$ in the investment goods sector. There are two consequences of this modification. First, from (8), one can see that the relative price of investment goods falls at a constant rate $g_{I^{-}} g_{C}$ in all countries. If $g_{I}>g_{C}$, this fits the stylized fact that the relative price of capital has steadily fallen in the postwar era. However, at any point in time, cross-country differences in the relative price of capital are still given by the cross-sectional distribution of $A_{I_{j}} /\left[A_{C_{j}}\left(1+\tau_{I_{j}}\right)\right]$. Second, the steady state share of labor in the capital goods sector is now given by

$$
L_{I_{j}} / L_{j}=\frac{\left(\bar{g}_{I}+\delta\right) \alpha\left(1-\tau_{K_{j}}\right)}{\left(1+\tau_{I_{j}}\right)\left[(1+\bar{g})^{1 / \sigma} / \beta-1+\delta\left(1-\tau_{K_{j}}\right)\right]} .
$$

Here $(1+\bar{g}) \equiv\left(1+g_{C}\right)^{I-\sigma}\left(1+g_{I}\right)^{\alpha /(1-\alpha)-\sigma}$ and $\left(1+\bar{g}_{I}\right) \equiv\left(1+g_{I}\right)^{I /(1-\alpha)}$. The domestic-price and international-price investment rates are still given by (11) and (13), except that the share of labor in the investment goods sector is now given by (3.1). Therefore, allowing for different rates of TFP growth in the two sectors affects the levels of investment rates. But as long as TFP growth rates do not differ across countries, our predictions about the forces underlying the correlation of PPP output per worker with the investment rates remain unchanged. 


\section{References}

Balassa, Bela (1964), “The Purchasing-Power Parity Doctrine: A Reappraisal,” Journal of Political Economy 72 (December), 584-596.

Ben-David, Dan (1998), “Convergence Clubs and Subsistence Economies,” Journal of Development Economics 55 (February), 153-169.

Bhagwati, Jagdish N. (1966), The Economics of Underdeveloped Countries, McGraw-Hill, New York.

Bhagwati, Jagdish N. (1984), "Why Are Services Cheaper in the Poor Countries?" Economic Journal 94 (June), 279-286.

Burstein, Ariel T., Joao C. Neves, and Sergio Rebelo (2000), "Distribution Costs and Real Exchange Rate Dynamics During Exchange-Rate-Based-Stabilizations," NBER Working Paper 7862 (August).

Carroll, Christopher D., Byung-Kun Rhee, and Chang-Yong Rhee (1994), "Are There Cultural Effects on Savings? Some Cross-Sectional Evidence,” Quarterly Journal of Economics 109 (August), 685-699.

Chari, V.V., Patrick J. Kehoe, and Ellen R. McGrattan (1996), “The Poverty of Nations: A Quantitative Exploration,” NBER Working Paper 5414 (January).

Chenery, Hollis B. and Alan M. Strout (1966), "Foreign Assistance and Economic Development," American Economic Review 56 (September), 679-733.

Collins, William and Jeffrey Williamson (2001), "Capital Goods Prices and Investment," Journal of Economic History 61 (March), 59-94.

DeLong, J. Bradford and Lawrence H. Summers, (1991) "Equipment Investment and Economic Growth," Quarterly Journal of Economics 106 (May), 445-502.

Diaz-Alejandro, Carlos (1970), Essays in the Economic History of the Argentine Republic, Yale University Press, New Haven, CT.

Easterly, William and Sergio Rebelo (1993), "Fiscal Policy and Economic Growth: An Empirical Investigation," Journal of Monetary Economics 32 (December), 417-458.

Easterly, William (2001), The Elusive Quest for Growth: Economists' Adventures and Misadventures in the Tropics, MIT Press, Cambridge, MA.

Eaton, Jonathan and Samuel Kortum (2001), “Trade in Capital Goods," European Economic Review 45 (June), 1195-1235. 
Erosa, Andrés and Ana Hidalgo Cabrillana (2003), "On Capital Market Imperfections as an Origin of Low TFP and Economic Rents," unpublished paper, University of Toronto.

Gersovitz, Mark (1983), "Savings and Nutrition at Low Incomes," Journal of Political Economy 91 (October), 841-855.

Gollin, Douglas (2002), "Getting Income Shares Right," Journal of Political Economy 110 (April), 458-474.

Gordon, Robert J. (1990), The Measurement of Durable Goods Prices, University of Chicago Press, Chicago, IL.

Greenwood, Jeremy, Zvi Hercowitz, and Per Krusell (1997), "Long-Run Implications of Investment-Specific Technological Change,” American Economic Review 87 (June), $342-362$.

Hall, Robert E. and Charles I. Jones (1999), "Why Do Some Countries Produce So Much More Output per Worker than Others?" Quarterly Journal of Economics 114 (February), 83116.

Heston, Alan, Robert Summers, Bettina Aten, and Daniel A. Nuxoll (1995), "New Kinds of Comparisons of the Prices of Tradables and Nontradables," CICUP Paper 95-3, University of Pennsylvania.

Heston, Alan, Robert Summers and Bettina Aten (2002), Penn World Table Version 6.1, Center for International Comparisons at the University of Pennsylvania (CICUP), December.

Higgins, Matthew and Jeffrey G. Williamson (1997), "Age Structure Dynamics in Asia and Dependence on Foreign Capital," Population and Development Review 23 (June), 261293.

Howitt, Peter (2000), "Endogenous Growth and Cross-Country Income Differences," American Economic Review 90 (September), 829-846.

Hummels, David and Peter J. Klenow (2002), “The Variety and Quality of a Nation's Exports," unpublished paper, Purdue University, December.

Imrohoroglu, Ayse and Krishna Kumar (2003), "Entry Costs, Intermediation, and Endogenous TFP Differences," unpublished paper, USC Marshall School of Business.

Jones, Charles I. (1994), "Economic Growth and the Relative Price of Capital," Journal of Monetary Economics 34 (December), 359-382.

Jovanovic, Boyan and Rafael Rob (1999), "Solow vs. Solow," unpublished paper, New York University. 
Klenow, Peter J. and Andrés Rodríguez-Clare (1997), "The Neoclassical Revival in Growth Economics: Has It Gone Too Far?” 1997 NBER Macroeconomics Annual, B. Bernanke and J. Rotemberg eds., MIT Press, Cambridge, Massachusetts, 73-103.

Lee, Jong-Wha (1995), "Capital Goods Imports and Long-Run Growth,” Journal of Development Economics 48 (September), 91-110.

Levine, Ross and David Renelt (1992), “A Sensitivity Analysis of Cross-Country Growth Regressions," American Economic Review 82 (September), 942-963.

Lewis, W. Arthur (1954), "Economic Development with Unlimited Supplies of Labor," Manchester School of Economic and Social Studies 22 (May), 139-191.

Matsuyama, Kiminori (1992), "Agricultural Productivity, Comparative Advantage, and Economic Growth,” Journal of Economic Theory 58 (December), 317-334.

McGrattan, Ellen R. and James A. Schmitz, Jr. (1999), "Explaining Cross-Country Income Differences," chapter 10 in the Handbook of Macroeconomics, Volume la, John B. Taylor and Michael Woodford, eds., North-Holland, New York, 669-737.

McKinnon, Ronald (1973), Money and Capital in Economic Development, Brookings Institution, Washington DC.

Mulligan, Casey B. (2002), “Capital, Interest, and Aggregate Intertemporal Substitution,” NBER Working Paper 9373 (December).

Nelson, Richard R. (1956), “A Theory of the Low-Level Equilibrium Trap in Underdeveloped Economies," American Economic Review 46 (December), 894-908.

Parente, Stephen L. and Edward C. Prescott (2000), Barriers to Riches, MIT Press, Cambridge, Massachusetts.

Pritchett, Lant (2000), "The Tyranny of Concepts: CUDIE (Cumulated, Depreciated, Investment Effort) Is Not Capital,’ Journal of Economic Growth 5 (December), 361-384.

Reinhart, Carmen and Kenneth Rogoff (2002), "The Modern History of Exchange Rate Arrangements: A Reinterpretation,” NBER Working Paper 8963 (May).

Restuccia, Diego and Carlos Urrutia (2001), "Relative Prices and Investment Rates," Journal of Monetary Economics 47 (February), 93-121.

Rostow, W.W. (1960), Stages of Economic Growth: A Non-Communist Manifesto, Cambridge University Press. 
Sala-i-Martin, Xavier (1997), “I Just Ran Four Million Regressions,” NBER Working Paper 6252 (November).

Samuelson, Paul A. (1964), "Theoretical Notes on Trade Problems," The Review of Economics and Statistics 46 (May), 145-154.

Schmitz, Jr. James A. (2001), "Government Production of Investment Goods and Aggregate Labor Productivity,” Journal of Monetary Economics 47 (February), 163-187.

Solow, Robert M. (1956), "A Contribution to the Theory of Economic Growth," Quarterly Journal of Economics 70 (February), 65-94.

Summers, Robert and Alan Heston (1991), "The Penn World Table (Mark 5): An Expanded Set of International Comparisons," Quarterly Journal of Economics 106 (May), 327-368.

Taylor, Alan M. (1998a), "Argentina and the World Capital market: Saving, Investment, and International Capital Mobility in the Twentieth Century," Journal of Development Economics 57 (October), 147-84.

Taylor, Alan M. (1998b), "On the Costs of Inward-Looking Development: Price Distortions, Growth, and Divergence in Latin America," Journal of Economic History 58 (March), $1-28$.

World Currency Yearbook (various years), Currency Data and Intelligence Inc. 